\title{
Carbon monoxide and related trace gases and aerosols over the Amazon Basin during the wet and dry seasons
}

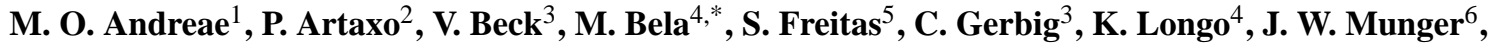 \\ K. T. Wiedemann ${ }^{2,6}$, and S. C. Wofsy ${ }^{6}$ \\ ${ }^{1}$ Biogeochemistry Department, Max Planck Institute for Chemistry, Mainz, Germany \\ ${ }^{2}$ Institute of Physics, University of São Paulo, São Paulo, Brazil \\ ${ }^{3}$ Max Planck Institute for Biogeochemistry, Jena, Germany \\ ${ }^{4}$ Center for Earth System Science (CCST), National Institute for Space Research (INPE), São José dos Campos, Brazil \\ ${ }^{5}$ Center for Weather Forecast and Climate Studies, National Institute for Space Research (INPE), Cachoeira Paulista, Brazil \\ ${ }^{6}$ Division of Engineering and Applied Science/Department of Earth and Planetary Science, Harvard University, Cambridge, \\ MA, USA \\ *now at: Laboratory for Atmospheric and Space Physics and Department of Atmospheric and Oceanic Sciences, University of \\ Colorado, Boulder, CO, USA
}

Correspondence to: M. O. Andreae (m.andreae@mpic.de)

Received: 9 March 2012 - Published in Atmos. Chem. Phys. Discuss.: 23 March 2012

Revised: 22 June 2012 - Accepted: 27 June 2012 - Published: 13 July 2012

\begin{abstract}
We present the results of airborne measurements of carbon monoxide (CO) and aerosol particle number concentration $(\mathrm{CN})$ made during the Balanço Atmosférico Regional de Carbono na Amazônia (BARCA) program. The primary goal of BARCA is to address the question of basinscale sources and sinks of $\mathrm{CO}_{2}$ and other atmospheric carbon species, a central issue of the Large-scale BiosphereAtmosphere (LBA) program. The experiment consisted of two aircraft campaigns during November-December 2008 (BARCA-A) and May-June 2009 (BARCA-B), which covered the altitude range from the surface up to about $4500 \mathrm{~m}$, and spanned most of the Amazon Basin.

Based on meteorological analysis and measurements of the tracer, $\mathrm{SF}_{6}$, we found that airmasses over the Amazon Basin during the late dry season (BARCA-A, November 2008) originated predominantly from the Southern Hemisphere, while during the late wet season (BARCA-B, May 2009) low-level airmasses were dominated by northernhemispheric inflow and mid-tropospheric airmasses were of mixed origin. In BARCA-A we found strong influence of biomass burning emissions on the composition of the atmosphere over much of the Amazon Basin, with CO enhancements up to $300 \mathrm{ppb}$ and $\mathrm{CN}$ concentrations approaching $10000 \mathrm{~cm}^{-3}$; the highest values were in the southern part of
\end{abstract}

the Basin at altitudes of $1-3 \mathrm{~km}$. The $\Delta \mathrm{CN} / \Delta \mathrm{CO}$ ratios were diagnostic for biomass burning emissions, and were lower in aged than in fresh smoke. Fresh emissions indicated $\mathrm{CO} / \mathrm{CO}_{2}$ and $\mathrm{CN} / \mathrm{CO}$ emission ratios in good agreement with previous work, but our results also highlight the need to consider the residual smoldering combustion that takes place after the active flaming phase of deforestation fires.

During the late wet season, in contrast, there was little evidence for a significant presence of biomass smoke. Low $\mathrm{CN}$ concentrations $\left(300-500 \mathrm{~cm}^{-3}\right)$ prevailed basinwide, and $\mathrm{CO}$ mixing ratios were enhanced by only $\sim 10 \mathrm{ppb}$ above the mixing line between Northern and Southern Hemisphere air. There was no detectable trend in $\mathrm{CO}$ with distance from the coast, but there was a small enhancement of $\mathrm{CO}$ in the boundary layer suggesting diffuse biogenic sources from photochemical degradation of biogenic volatile organic compounds or direct biological emission.

Simulations of CO distributions during BARCA-A using a range of models yielded general agreement in spatial distribution and confirm the important contribution from biomass burning emissions, but the models evidence some systematic quantitative differences compared to observed $\mathrm{CO}$ concentrations. These mismatches appear to be related to problems with the accuracy of the global background fields, the role 
of vertical transport and biomass smoke injection height, the choice of model resolution, and reliability and temporal resolution of the emissions data base.

\section{Introduction}

On 14 November 1981 - just over $30 \mathrm{yr}$ ago - the first global image of the tropospheric distribution of carbon monoxide (CO) was obtained by the NASA Measurement of Air Pollution from Space (MAPS) experiment during the STS-2 space shuttle mission (Reichle et al., 1986). Only a few orbits yielded useful data, but one feature stood out clearly: strongly elevated $\mathrm{CO}$ concentrations both east and west of the Amazon Basin. The authors wrote: "Whether this CO results from photochemical processes, from biomass burning, or from some other source is not clear." The hypothesis that the Amazonian CO plume was largely the result of the photooxidation of isoprene and other volatile organic compounds (VOCs) was the basis of the experimental design of the NASA Amazon Boundary Layer Experiments (ABLE-2A and -2B), conducted in 1985 and 1987 (Harriss et al., 1988, 1990a). Extensive CO measurements during these campaigns did show evidence of significant contributions of VOC photooxidation to the atmospheric CO burden; however, biomass burning was identified as the dominant source of the CO plume (Andreae et al., 1988; Jacob and Wofsy, 1988; Sachse et al., 1988; Harriss et al., 1990b; Kirchhoff and Marinho, 1990). Since these early investigations, interest in the distribution and sources of $\mathrm{CO}$ over Amazonia, and over the tropics in general, has persisted, with remote sensing playing an increasingly important role (Kirchhoff and Rasmussen, 1990; Reichle et al., 1990, 1999; Alvala and Kirchhoff, 1998; Pougatchev et al., 1999; Edwards et al., 2006; Yurganov et al., 2008, 2010). These studies confirmed the existence of a persistent CO maximum over the Amazon Basin and its periphery, which is particularly prominent during the fire season that occurs in the period from August to December.

Interest in the atmospheric cycle of $\mathrm{CO}$ is motivated by its central role in atmospheric chemistry as a product of the photooxidation of methane $\left(\mathrm{CH}_{4}\right)$ and other VOCs, as the dominant sink for the $\mathrm{OH}$ radical, and as a precursor of tropospheric ozone $\left(\mathrm{O}_{3}\right)$ (Logan et al., 1981). The main sources of $\mathrm{CO}$ globally are fossil fuel combustion, biofuel use, and industrial emissions $\left(500-900 \mathrm{Tg} \mathrm{a}^{-1}\right), \mathrm{CH}_{4}$ oxidation (700-900 $\mathrm{Tg} \mathrm{a}^{-1}$ ), oxidation of non-methane VOCs $\left(500-700 \mathrm{Tg} \mathrm{a}^{-1}\right)$, and biomass burning $\left(400-800 \mathrm{Tg} \mathrm{a}^{-1}\right)$, based on bottom-up emission inventories and on inverse analyses of atmospheric data (Holloway et al., 2000; Duncan et al., 2007). While at the global and annual scale the four main $\mathrm{CO}$ sources are of comparable magnitude, their spatial and temporal variations result in distinctive spatio-temporal patterns of the atmospheric distribution of $\mathrm{CO}$. The oxidation of $\mathrm{CH}_{4}$, a long-lived trace gas with fairly even global dis- tribution, results in an almost uniform $\mathrm{CO}$ background of about $25 \mathrm{ppb}$ worldwide, whereas fossil fuel derived emissions dominate in the northern mid-latitudes (Holloway et al., 2000; Duncan and Logan, 2008). On a seasonal time scale, fossil fuel emissions dominate $\mathrm{CO}$ sources in winter in North America, while oxidation of $\mathrm{CH}_{4}(35 \%)$ and biogenic nonmethane VOCs $(21 \%)$, among which isoprene makes by far the largest contribution, are the largest sources of $\mathrm{CO}$ in summer (Miller et al., 2008).

Over the tropical continents, biomass burning and VOC oxidation make the most prominent contributions to atmospheric CO, especially in the lower troposphere (Duncan et al., 2007). VOC oxidation shows relatively little seasonal and spatial variability over the tropical continents, and thus provides a relatively smooth background, which may account for a considerable fraction of the $\mathrm{CO}$ burden in the lower troposphere there (Holloway et al., 2000; Duncan and Logan, 2008). In contrast, biomass burning occurs mainly during the dry season and along the margins of the rain forest. This feature, in combination with the fact that $\mathrm{CO}$ is readily detected by remote sensing, makes the gas an excellent tracer for emissions from biomass burning (Edwards et al., 2006; Gatti et al., 2010; Yurganov et al., 2010).

Aerosol particles are emitted from vegetation fires by the same processes that produce $\mathrm{CO}$, in particular the pyrolysis and smoldering phases of combustion (Andreae and Merlet, 2001). Since, like CO, they are easily measured both in-situ and by remote sensing, they are also well suited as tracers for biomass burning emissions, especially in regions where other aerosol sources are relatively weak (Kaufman et al., 1990, 2002; Edwards et al., 2006). The utility of CO and aerosols as biomass burning tracers is enhanced when both are used in combination, as they are emitted at a strikingly consistent ratio from a wide variety of fires. The ratio of excess particle number concentration $(\mathrm{CN})$ to excess $\mathrm{CO}(\Delta \mathrm{CN} / \Delta \mathrm{CO})$ from biomass burning is about $30 \pm 15 \mathrm{~cm}^{-3} \mathrm{ppb}^{-1}$ (Guyon et al., 2005; Andreae and Rosenfeld, 2008; Janhäll et al., 2010; Kuhn et al., 2010). Urban emissions, in contrast, have much higher $\Delta \mathrm{CN} / \Delta \mathrm{CO}$ ratios owing to the more efficient combustion and thus lower $\mathrm{CO}$ emissions from vehicles and power plants (Nicks et al., 2003; Kuhn et al., 2010).

Aerosol studies over Amazonia started during the 1980s as parts of the ABLE campaigns (Andreae et al., 1988, 1990; Artaxo et al., 1988, 1990; Talbot et al., 1988, 1990) and numerous papers have been published since (for a review, see Martin et al., 2010). These studies show that the Amazonian aerosol comes from a mixture of internal and external sources: The rainforest biota provide the dominant source of coarse mode particles (diameter $>1 \mu \mathrm{m}$ ) in the form of primary biogenic aerosols (fungal spores, leaf detritus, microbes, etc.), while the oxidation of biogenic VOCs to secondary organic aerosol (SOA) is the most important contribution to fine mode $(<1 \mu \mathrm{m})$ aerosols outside the burning season (Chen et al., 2009; Pöschl et al., 2010; Gilardoni et al., 2011). Pyrogenic (biomass burning) aerosols from fires in 
the periphery of the Amazon forest dominate the fine mode in the dry season, but given that Amazonia is downwind of Africa with its huge vegetation fires, smaller amounts of pyrogenic aerosols from long-range transport are almost ubiquitous and ever-present. Finally, advection in the northeastern trade winds, especially in the early part of the year, brings in substantial amounts of dust from Africa and marine aerosol from the Atlantic Ocean (Andreae et al., 1990; Talbot et al., 1990; Swap et al., 1992; Formenti et al., 2001; Ben-Ami et al., 2009, 2010; Baars et al., 2011). Changing aerosol burdens over Amazonia as a result of human activities are thought to have significant consequences for ecology and climate, e.g., by perturbing the flux of photosynthetically active radiation (Schafer et al., 2002; Oliveira et al., 2007), reducing the amount of convective clouds (Koren et al., 2004), and affecting the intensity and distribution of precipitation (Rosenfeld, 1999; Andreae et al., 2004; Lin et al., 2006; Jiang et al., 2008; Martins et al., 2009).

The results presented here were obtained as part of the Balanço Atmosférico Regional de Carbono na Amazônia (BARCA) aircraft measurement program, which has as its primary goal to address the question of basin-scale sources and sinks of $\mathrm{CO}_{2}$, a central issue of the Large-scale Biosphere-Atmosphere Experiment in Amazonia (LBA) program. BARCA addresses the "missing scale" for measurements of $\mathrm{CO}_{2}$ and other fluxes, those intermediate between local and global. Process- and ecosystem-level studies, such as continuous eddy correlation fluxes or allometry, have supplied detailed information about carbon exchange by individual patches of forest (e.g., Fan et al., 1990; Grace et al., 1995a, b; Andreae et al., 2002; Carswell et al., 2002; Saleska et al., 2003; Chambers et al., 2004; von Randow et al., 2004). A somewhat larger scale (tens to hundreds of kilometers) has been addressed by sequential vertical profiles at fixed locations (Lloyd et al., 2007; Gatti et al., 2010). Inverse studies couple marine boundary-layer observations and atmospheric transport models to yield carbon fluxes at global or hemispheric scales (Schimel et al., 2001), but have not succeeded at regional to continental scales due to lack of data over continents and uncertainties in transport modeling (Gloor et al., 1999). The strategy of the BARCA campaigns was based on Lagrangian airborne measurements of $\mathrm{CO}_{2}, \mathrm{CO}, \mathrm{CH}_{4}$, and $\mathrm{H}_{2} \mathrm{O}$ within and above the planetary boundary layer (PBL) to provide constraints on regional fluxes, and large-scale surveys of the trace gas distributions along the synoptic flow pattern to give basin-scale flux constraints. These concepts have been previously applied in Amazonia during the ABLE-2A and ABLE-2B campaigns (Wofsy et al., 1988; Chou et al., 2002), and over North America in the $\mathrm{CO}_{2}$ Budget and Rectification Airborne (COBRA) study (Gerbig et al., 2003a, b; Lin et al., 2004).

The BARCA experiment consisted of two aircraft campaigns during November-December 2008 (BARCA-A) and May-June 2009 (BARCA-B). The measurements covered the altitude range from the surface up to about $4500 \mathrm{~m}$, and spanned across the Amazon Basin. We conducted measurements of $\mathrm{CO}$ and aerosol particle concentrations on the BARCA flights to address the following questions: What are the distributions of $\mathrm{CO}$ and aerosol particles in time and space over the Amazon Basin? What are the sources of CO and aerosol particles in the Amazon region? How can $\mathrm{CO}$ be used as a source-specific tracer for $\mathrm{CO}_{2}, \mathrm{CH}_{4}$, and aerosols over the region? In this paper, we will present the results of our measurements and discuss them in the context of the BARCA scientific objectives.

\section{Methods}

\subsection{Aircraft sampling}

The research flights were conducted using the twin-engine EMB 110 Bandeirante aircraft of the Brazilian Instituto Nacional de Pesquisas Espaciais (INPE) (Kirchhoff and Alvalá, 1996), carrying a payload that comprised instruments for real-time measurements of $\mathrm{CO}_{2}, \mathrm{CH}_{4}, \mathrm{CO}, \mathrm{O}_{3}, \mathrm{H}_{2} \mathrm{O}$, aerosol number concentration and optical properties. In addition, a flask sampling system allowed the collection of discrete samples for the determination of $\mathrm{CO}_{2}, \mathrm{CH}_{4}, \mathrm{SF}_{6}, \mathrm{CO}$, $\mathrm{N}_{2} \mathrm{O}, \mathrm{H}_{2}$, and $\mathrm{O}_{2} / \mathrm{N}_{2}$. In order to minimize the influences of wing tip vortices and the distorted flow that may be created by the nose and windshield areas on the fuselage, the sampling inlets were located on the lower aircraft fuselage forward of the propellers. The inlet lines were made from stainless steel tubing of $11.5 \mathrm{~mm}$ inner diameter with a bend radius of $100 \mathrm{~mm}$. The intakes for $\mathrm{CO}$ and $\mathrm{CN}$ measurements were 185 and $70 \mathrm{~mm}$ from the fuselage, respectively. Sample air for the particle number and $\mathrm{CO}$ measurements were taken from forward facing inlets, and large pressure differentials were avoided by sub-sampling from a pipe that was vented outside. Apart from the internal heat of the instruments, no drying was applied to the particles.

Flasks were taken during each vertical profile with an altitude spacing of about $1 \mathrm{~km}$ using a manual sampling system. After flowing through a rearward facing inlet tube (Dekabon $0.62 \mathrm{~mm}$ outer diameter, $4 \mathrm{~m}$ length), the sample air passed through a dryer $\left(\mathrm{MgClO}_{3}\right)$ followed by a Teflon filter (1 $\mu \mathrm{m})$, a membrane pump (KNF PJ 16623-86), a back strike valve, and entered the flask (volume $1 \mathrm{~L}$, borosilicate glass 3.3, Kel-F® (PCTFE) valve seals, manufacturer NORMAG, Germany). Downstream of the flask the air passed through a set of valves allowing for flushing of the flask (to remove the influence from the conditioning air contained in the flasks) and for pressurization to $150 \mathrm{kPa}$ above cabin pressure (60$100 \mathrm{kPa}$ ). At a sample flow of about $4 \mathrm{~L} \mathrm{~min}^{-1}$, the typical flushing time was $2 \mathrm{~min}$, and pressurization was achieved typically after another $30 \mathrm{~s}$. 


\subsection{Airborne real-time measurements}

Carbon monoxide (CO) was measured at 2-s time resolution by UV resonance fluorescence, using a Fast-CO-Monitor (Model AL 5002, Aerolaser GmbH, Germany). Prior to measurement, the air was dried using a Nafion drier. The precision of the $0.5 \mathrm{~Hz}$ data was $0.6 \%$, based on the variability of the 2-s measurements of the standard gas within each 30-s calibration period. In flight, zero and span calibrations were made every $10 \mathrm{~min}$ to account for instrumental drift associated with varying pressure and temperature. The instrument was zeroed and the span adjusted following each calibration. At the end of the 10-min interval, the mixing ratio in the calibration gas was determined relative to the nominal value set at the beginning of the calibration period. This measurement reflects the drift over the 10-min measurement cycle and gives an upper limit of the error of the measurements relative to the nominal mixing ratio in the calibration gas. The standard deviation of these measurements was $1.9 \%$ for BARCA-A and $1.2 \%$ for BARCA-B. The nominal value of the calibration gas mixing ratio (1005.7 ppb) had been obtained at the Max Planck Institute for Biogeochemistry by measurements relative to a calibration gas traceable to the WMO $2004 \mathrm{CO}$ mole fraction scale (Novelli et al., 2003). To verify the accuracy of the real-time versus the flask measurements (see below) we regressed the in-situ values against the simultaneously obtained flask data. For BARCA-A we obtained CO(realtime $)=-(6.3 \pm 2.1)+(0.995 \pm 0.014) \cdot \mathrm{CO}($ flask $)\left(R^{2}=0.99\right)$. For BARCA-B there was a relatively poor fit; $\mathrm{CO}$ (realtime $)=-(2.2 \pm 3.6)+(0.924 \pm 0.040) \cdot \mathrm{CO}($ flask $)\left(R^{2}=0.75\right)$. The intercept of $-2.2 \pm 3.6 \mathrm{ppb}$ is within the standard error the same as on BARCA-A, and if an intercept of -5.8 is forced, the slope becomes 0.96. A similar intercept had been obtained for the flask and in-situ data obtained at the ZOTTO station in Siberia, where the same type of flasks and instrumentation is used (Vasileva et al., 2011), and is most likely due to $\mathrm{CO}$ production in the flasks during storage (see below). To bring the airborne real-time and flask data onto the same scale, the regression equations above were used to adjust the flask values to the in-situ scale.

Total particle number concentration $(\mathrm{CN})$ was measured at $1 \mathrm{~s}$ time resolution using a TSI 3010 Condensation Particle Counter (CPC 3010, TSI Inc., USA). The instrument is efficient for particles with diameters between about $10 \mathrm{~nm}$ and $1 \mu \mathrm{m}$. Data were corrected for coincidence using the manufacturer's suggested equation:

$N_{\mathrm{a}}=N_{\mathrm{i}} e^{N_{\mathrm{a}} \cdot Q \cdot t}$

where $N_{\mathrm{a}}$ is the actual concentration $\left(\mathrm{cm}^{-3}\right), N_{\mathrm{i}}$ is the indicated concentration $\left(\mathrm{cm}^{-3}\right), Q$ the sample air flow rate $\left(16.67 \mathrm{~cm}^{3} \mathrm{~s}^{-1}\right), t$ the effective time each particle resides in the viewing volume $(0.4 \mathrm{~ms})$, and $N_{\mathrm{a}}$ in the exponent is approximated by $N_{\mathrm{i}}$. Particle number concentrations have been normalized to standard air pressure $(1000 \mathrm{hPa})$ and temperature $(273.15 \mathrm{~K})$

Concentrations of $\mathrm{CO}_{2}$ were measured using the airborne analyzer described by Daube et al. (2002), a repackaging of a LiCor 6251 non-dispersive infrared gas analyzer originally developed for the NASA ER-2 aircraft in the 1990s and flown for thousands of hours in both the troposphere and stratosphere. All samples were dried using a Nafion drier followed by a dryice trap, and referenced in flight at $20 \mathrm{~min}$ intervals to low-, mid- and high-span standards traceable to WMO standard gases.

\subsection{Flask measurements}

The flask samples were analyzed at the MPI Jena Gaslab 120 to 300 days after sampling, with most of the delay due to customs. Laboratory tests have shown that the PCTFE valve seals result on average in an increase in $\mathrm{CO}$ of $1.3 \mathrm{ppb}$ over a two month period, which would correspond to a $2.6-6.5 \mathrm{ppb}$ increase for the BARCA samples, and can account for the offset between real-time and flask $\mathrm{CO}$ measurements. Other species show virtually no drift in the flasks, which is a significant improvement compared to traditional valve seals made of PFA. Samples were analyzed for CO using a Trace Analytical Reduction Gas Analyzer (RGA), referenced to CO standards traceable to the WMO 2004 CO mole fraction scale (Novelli et al., 2003) with a precision of $0.5 \mathrm{ppb}$, and adjusted for the offset against the real-time data using the equations given above. $\mathrm{SF}_{6}$ analysis was performed using a GC-ECD and referenced to the NOAA-2006 $\mathrm{SF}_{6}$ scale with a precision of 0.03 ppt.

\subsection{Ground-based measurements}

$\mathrm{CO}$ and $\mathrm{CO}_{2}$ mixing ratios were measured at Maxaranguape (designated MXR; $5^{\circ} 29^{\prime} \mathrm{S}, 35^{\circ} 16^{\prime} \mathrm{W}$ ), a coastal site north of Natal operated by INPE-CRN (Kirchhoff et al., 2003), and at the LBA-ECO SAN (km67) flux-tower site in the Flona Tapajos Nacional near Santarem (designated SAN; $2^{\circ} 51^{\prime} \mathrm{S}$, $54^{\circ} 58^{\prime} \mathrm{W}$ ) (Saleska et al., 2003) (Fig. 1). Observations at MXR are dominated by onshore winds and represent air in the tropical marine boundary layer. SAN is $775 \mathrm{~km}$ from the coast, and air samples from this site during predominantly easterly winds are affected by emissions from forest and agricultural lands in the eastern Amazon basin.

At both sites $\mathrm{CO}$ was measured using a Thermo Environmental Instruments infra-red absorption analyzer (TEI 48 CTL). The sample air and calibration are brought to a dewpoint of $2{ }^{\circ} \mathrm{C}$ to minimize water vapor interferences. The analyzer is zeroed every $15 \mathrm{~min}$ by passing the ambient sample air over a Sofnocat catalyst to remove CO. The analyzer is calibrated 4 times per day with 100 and 500 ppb standard gases. Additionally, $\mathrm{CO}_{2}$ mixing ratios are measured at both sites using a LiCOR (6262) infrared gas analyzer that is calibrated 2-4 times a day with $\mathrm{CO}_{2}$ standards traceable 


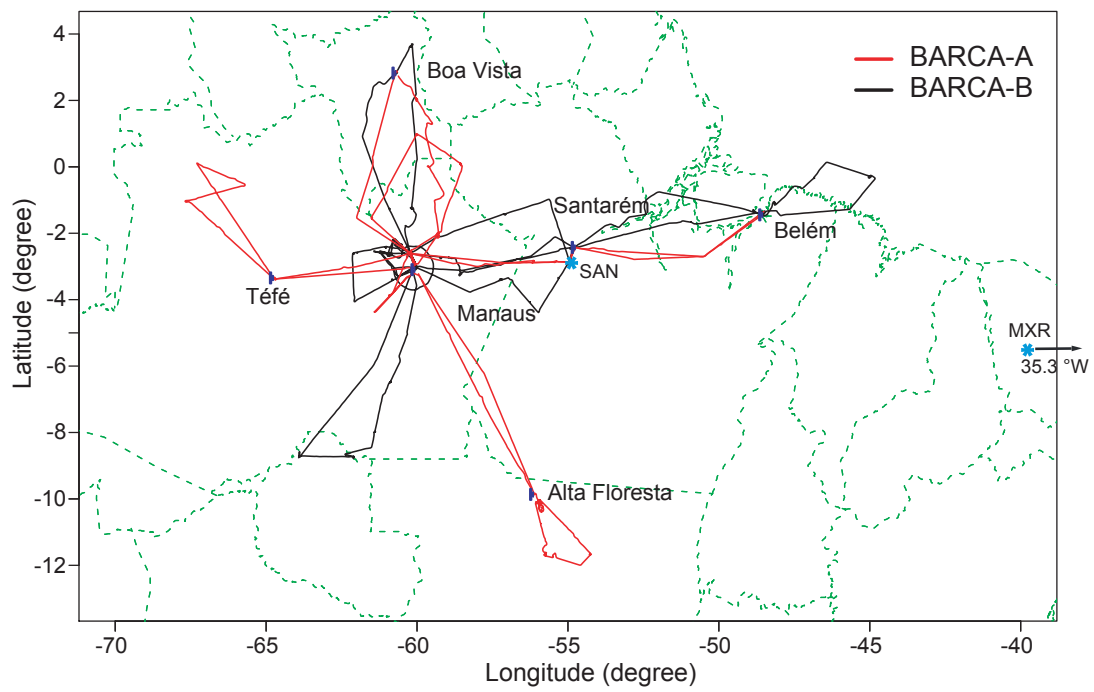

Fig. 1. Flight tracks of the BARCA aircraft campaigns (red: BARCA-A, black: BARCA-B). The ground measurement sites SAN and MXR are indicated by blue stars.

to CMDL primary standards. The sample air at SAN was not dried, and $\mathrm{CO}_{2}$ mixing ratios are corrected for simultaneously measured water vapor. At MXR, sample air was dried using a Nafion dryer in order to reduce problems with condensation in the sample lines and minimize the water vapor correction terms.

Measurements began at SAN in April 2001, and were nearly continuous save for occasional down periods for malfunction and delays in obtaining calibration gas, until the tower was destroyed by a falling tree in January 2006. The tower was restored and $\mathrm{CO}$ and $\mathrm{CO}_{2}$ instruments resumed operation in November 2008 for the BARCA flight campaign period and were in operation during the interval between flight campaigns $\mathrm{A}$ and $\mathrm{B}$. Measurements of $\mathrm{CO}$ at MXR began in December 2002 and those of $\mathrm{CO}_{2}$ in July 2004. Sporadic outages induced by power problems and occasional instrument failures introduced data gaps in the long term record prior to the BARCA campaigns.

\subsection{Transport modeling}

\subsubsection{STILT}

To assess trace gas source regions, time reversed Lagrangian particle dispersion model simulations were made using STILT (Stochastic Time Inverted Lagrangian Transport, Lin et al., 2003) for different receptor locations along the flight track. STILT has been applied to a number of airborne studies (Gerbig et al., 2003b; Lin et al., 2003, 2004; Xueref et al., 2004; Matross et al., 2006; Kort et al., 2008; Macatangay et al., 2008; Miller et al., 2008; Pillai et al., 2011). Details of the model can be found in Gerbig et al. (2003b); here we only provide a short description of the setup. For the BARCA campaigns, STILT was driven by meteorological data from
ECMWF (00:00 and 12:00 analysis fields combined with short term forecast fields) with 3 hourly time resolution and a spatial resolution of $1 / 4$ by $1 / 4$ degrees for a domain covering most of South America (South-West corner: $35^{\circ} \mathrm{S} 85^{\circ} \mathrm{W}$, North-East corner: $15^{\circ} \mathrm{N} 30^{\circ} \mathrm{W}$ ). For each receptor location, an ensemble of 100 particles was released and the back trajectories were followed for 15 days. Footprints (sensitivity of mixing ratios at the receptor to upstream surface fluxes, in units of ppm per $\mu \mathrm{mol} \mathrm{m} \mathrm{m}^{-2} \mathrm{~s}^{-1}$ ) at the horizontal resolution of $1 / 4$ by $1 / 4$ degrees were derived from the trajectories of ensembles containing 100 particles, following Gerbig et al. (2003b).

For CO tracer simulations with STILT for the BARCAA period we used fossil fuel emissions based on the Emission Database for Global Atmospheric Research (EDGAR), release version 4.1 (European Commission, Joint Research Centre/Netherlands Environmental Assessment Agency; http://edgar.jrc.ec.europa.eu/), and biomass burning emissions calculated based on the Brazilian Biomass Burning Emission Model (3BEM) (Longo et al., 2010), which is included in the PREP-CHEM-SRC preprocessor using GOES (Geostationary Operational Environmental Satellite), AVHRR (Advanced Very High Resolution Radiometer) and MODIS (Moderate-Resolution Imaging Spectroradiometer) data (Freitas et al., 2011). This preprocessor has been adapted to provide daily biomass burning emissions on the Cartesian grid used by STILT. A diurnal cycle modulating the biomass burning emissions, peaking around 14:00 local time, was adapted from Longo et al. (2010). Lateral boundary conditions for $\mathrm{CO}$ were taken from the GEMS re-analysis (downloaded from http://data-portal.ecmwf.int/data/d/gems reanalysis/). The STILT simulations treat $\mathrm{CO}$ as an inert tracer, in accordance with previous studies (Longo et al., 
2010); no photochemical loss (through reaction with $\mathrm{OH}$ ) or production (from oxidation of biogenic VOCs) was taken into account during the time of transport from the domain boundary to the measurement locations. The missing photochemical sink partially compensates for the missing source, but as the source from biogenic VOCs contributes more to the lower atmosphere, we expected to see a small bias in the vertical gradient. However, the expected signature from photochemistry was small compared to the strong biomass burning contribution during BARCA-A. In addition to the STILT CO simulation using ECMWF meteorological fields, we alternatively used the fields generated by the WRF-GHG run at $30 \mathrm{~km}$ and at hourly output to drive STILT (Nehrkorn et al., 2010).

\subsubsection{WRF-GHG}

Further simulations of $\mathrm{CO}$ were performed with different weather prediction, chemistry, and transport models, using identical biomass burning emissions and nearly identical fossil fuel emissions. These results are intended to provide insight into our current understanding of atmospheric transport in the Amazon region. WRF-GHG, a combination of the Weather Research and Forecasting model with Chemistry (WRF-Chem) (Grell et al., 2005) with the GreenHouse Gas module (Beck et al., 2011) that allows for passive tracer transport of $\mathrm{CO}_{2}, \mathrm{CH}_{4}$, and $\mathrm{CO}$, was used in tagged tracer mode for $\mathrm{CO}$ to simulate the contributions from different source components. In this model also, $\mathrm{CO}$ was treated as a passive tracer, ignoring photochemical production and loss. Lateral and surface boundary conditions for meteorological fields and $\mathrm{CO}$ were identical to those used in STILT. WRFGHG was run at horizontal resolutions of $30 \mathrm{~km}$ and $10 \mathrm{~km}$ to assess the potential impact of the model resolution. The $30 \mathrm{~km}$ horizontal resolution model domain was chosen to match the one used for STILT, and the $10 \mathrm{~km}$ horizontal resolution domain covered the BARCA flight area. WRF-GHG simulations were carried out for a one month period (November 2008) with daily re-initialization of the ECMWF meteorological fields. Similar to the WRF-Chem simulations, more up-to-date data for several land-surface variables (albedo, greenness fraction, and vegetation coverage) replaced the standard WRF-Chem data, and ECMWF soil moisture was substituted with the GPNR soil moisture product (Gevaerd and Freitas, 2006). Fossil fuel and biomass burning emissions were identical for both WRF simulations (WRF-GHG and WRF-Chem) and similar to those used in STILT. Differences in the two WRF simulations are rooted in the different horizontal resolutions, the selection of different physics schemes, and the initialization of the meteorological fields. For WRF-GHG simulations, the Grell-Devenyi convection option, the Mellor-Yamada-Janjic (MYJ) planetary boundary layer scheme, and the WRF Single Moment (WSM) 5-class microphysics scheme were selected.

\subsubsection{WRF-Chem and CCATT-BRAMS}

In addition, simulations with full chemistry were conducted with the CCATT-BRAMS (Longo et al., 2010) and WRFChem chemistry/transport models. Both models were run in a two-way nested grid configuration, with a $140-\mathrm{km}$ grid covering Africa and South America (South-West corner: $60^{\circ} \mathrm{S}, 100^{\circ} \mathrm{W}$, North-East corner: $\left.20^{\circ} \mathrm{N}, 50^{\circ} \mathrm{W}\right)$ and a $35 \mathrm{~km}$ grid covering most of South America (South-West corner: $35^{\circ} \mathrm{S} 85^{\circ} \mathrm{W}$, North-East corner: $\left.15^{\circ} \mathrm{N}, 30^{\circ} \mathrm{W}\right)$. The outer WRF-Chem grid was expanded to include the crossAtlantic transport of biomass burning emissions from southern Africa, and the inner grid had a $35 \mathrm{~km}$ resolution covering South America, while WRF-GHG used a $30 \mathrm{~km}$ grid covering South America and a $10 \mathrm{~km}$ domain over the Amazon region. CCATT-BRAMS and WRF-Chem were initialized on 1 October 2008 00:00 UTC and driven by the NCEP GFS analysis (downloaded from http://dss.ucar.edu/datasets/ ds083.2/) with a 6 hourly time resolution and $1^{\circ}$ by $1^{\circ}$ spatial resolution. Chemistry initial and boundary conditions were provided by MOCAGE 6 hourly forecasts (Peuch et al., $1999)$ with a $\mathrm{T} 42\left(\sim 0.2^{\circ}\right)$ spatial resolution. Emissions were generated with PREP-CHEM-SRC, using the same 3BEM biomass burning emissions as for STILT and WRF-GHG, while anthropogenic emissions were estimated from the RETRO, GOCART and EDGARv4.0 global databases updated with South American inventories (Alonso et al., 2010), and biogenic emissions were provided by the MEGAN 2000 climatology. This climatology does not include diurnal variation in emissions. In WRF-Chem, biogenic emissions were combined with the anthropogenic emissions and a Gaussian diurnal cycle with peak at 15:00 UTC (11LT) is applied. In CCATT the diurnal cycle of biogenic emissions follows exactly the same shape as the solar radiation cycle. In the full chemistry simulations (WRF-Chem and CCATT-BRAMS), the RACM chemical mechanism was used (Stockwell et al., 1997).

\subsubsection{HYSPLIT4}

To assess transport across the Atlantic, backward trajectories were calculated using the vertical motion model in the HYSPLIT4 (HYbrid Single-Particle Lagrangian Integrated Trajectory) program with the GDAS meteorological database at the NOAA Air Resources Laboratory web server (Draxler and Rolph, 2003). Back trajectory calculations were started at 500 and $4000 \mathrm{~m}$ above ground level. For statistical analysis of the data, the SPSS 13.0 (SPSS Inc., Chicago, IL, USA) package was used. 


\section{Results and discussion}

\subsection{Sampling period and region}

The BARCA measurement flights took place during two aircraft campaigns, BARCA-A from 16 November to 2 December 2008 and BARCA-B from 15 to 28 May 2009. The flight tracks (Fig. 1) spanned much of the Brazilian Amazon, from São Gabriel da Cachoeira in the northwest to the Atlantic off of Belém in the east, and from Boa Vista in the north to Sinop in the south. Aircraft limitations constrained the altitude range to a ceiling of ca. $4500 \mathrm{~m}$. The flights were typically conducted as a sequence of alternating climbing and descending profiles, with brief (5-30 min) horizontal legs at the ceiling altitude, or just above the tree tops, in between profiles. The objective of these flight patterns was to obtain 2-dimensional east-west and north-south sections across the Amazon Basin.

\subsection{Meteorological background and campaign setting}

The Intertropical Convergence Zone (ITCZ) undergoes large seasonal shifts in the Amazon Basin. During boreal summer it moves to the north, such that in July almost the entire Basin is south of the ITCZ, and thus lies in the Southern Hemisphere (SH) both meteorologically and geographically. In contrast, during austral summer the ITCZ can move as far south as $20^{\circ} \mathrm{S}$, so that a large part of the Basin is in the meteorologically Northern Hemisphere (NH). This shift has important consequences for both the prevailing weather and the atmospheric composition in the study region.

During late November 2008, when BARCA-A took place, the ITCZ was north of the study region, which therefore received predominantly SH airmasses. (Below, we will show evidence for this, based on the chemical tracer sulfur hexafluoride, $\mathrm{SF}_{6}$.) Figure 2 (left half) shows (a) the distribution of vegetation fires, (c, e) 10-day trajectory ensembles for the two campaign periods ending at a location near Manaus at 500 and $4000 \mathrm{~m}$ height (calculated with HYSPLIT), and (g) surface flux footprints (calculated with the STILT model). The fire distribution is represented by the mean fire radiative power (FRP), a proxy for the amount of biomass burned, over the BARCA-A period, using data from the Monitoring Atmospheric Composition and Change (MACC) Fire Intensity Product (Kaiser et al., 2012). The trajectory ensembles show that the airmass transport during BARCA-A in both in the planetary boundary layer (PBL) and in the free troposphere (FT) was almost exclusively from the SH. While there is a very high density of fires in West Africa during this period, no PBL and few FT trajectories cross the fire locations, suggesting that this source is not of major importance for pollutant levels in the study area. The STILT footprint analysis and the PBL trajectories show that source locations in the eastern part of Amazonia (where fires were widespread during the campaign) were dominant both for trace gas exchange with the biosphere and for pollutant (smoke) emissions.

In contrast, during BARCA-B in late May 2009 (Fig. 2, right half), the study area straddled the ITCZ. Surface trajectories came mostly from the $\mathrm{NH}$, particularly the tropical North Atlantic, and may have brought in some of the pyrogenic emissions from some moderately active fire areas in West Africa. Since the ITCZ lies well north of the equator in Africa during this time of year, the trajectory cluster that reaches into Central Africa (Fig. 2d) likely brought in air with SH characteristics. The trajectories in the FT cover a large area on both sides of the ITCZ. Fire activity in the Amazon region was scattered and weak during this period. The STILT footprint mostly follows a region in eastern Amazonia along the Amazon River and does not include any regions with strong fire activity.

Sulfur hexafluoride, $\mathrm{SF}_{6}$, in the atmosphere is a trace gas of almost exclusively anthropogenic origin (Levin et al., 2010). Since its sources are mostly in the NH, there is a distinct concentration gradient between the hemispheres. For reference, the $\mathrm{SF}_{6}$ mixing ratios at the NOAA ESRL monitoring stations Ragged Point, Barbados (RPB, $\left.13^{\circ} \mathrm{N}, 59^{\circ} \mathrm{W}\right)$, Arembepe, Brazil (ABP, $12^{\circ} \mathrm{S}, 38^{\circ} \mathrm{W}$ ), and Ascension Island (ASC, $7^{\circ} \mathrm{S}, 14^{\circ} \mathrm{W}$ ) during the BARCA campaigns are plotted in Fig. 3. The $\mathrm{SF}_{6}$ mixing ratios from the BARCAA flights show only a slight latitudinal gradient, and are all fairly close to the SH values represented by ABP and ASC. We calculated the fraction of $\mathrm{NH}$ air in the samples from BARCA-A using the $\mathrm{SF}_{6}$ mixing ratios at $\mathrm{ABP}$ and $\mathrm{ASC}$ (average $6.45 \mathrm{ppt}$ ) and $\mathrm{RPB}(6.68 \mathrm{ppt})$ as representative of $\mathrm{SH}$ and $\mathrm{NH}$ air, respectively, and found the median $\mathrm{NH}$ air contribution to be $18 \%$ during BARCA-A. The few higher values seen near $3^{\circ} \mathrm{S}$ are from the FT on the flight to Tefé and may represent intrusions of $\mathrm{NH}$ air in the more western part of the Basin. No systematic difference is seen between PBL and FT mixing ratios. This provides strong evidence that during BARCA-A the entire study region was dominated by air from the $\mathrm{SH}$.

The $\mathrm{SF}_{6}$ results from BARCA-B, on the other hand, support the conclusions already drawn from the trajectory analysis, i.e., that the study region straddled the ITCZ and that air from both hemispheres was sampled during this campaign. The average $\mathrm{SF}_{6}$ mixing ratio from BARCA-B $(6.67 \mathrm{ppt})$ indicates approximately equal contributions of $\mathrm{NH}$ and $\mathrm{SH}$ air (6.80 and $6.58 \mathrm{ppt}$, respectively). In contrast to the trajectory analysis, which suggested a stronger contribution of $\mathrm{NH}$ air in the PBL, the $\mathrm{SF}_{6}$ data show no significant difference between the PBL and FT. The southernmost flights of BARCA$\mathrm{B}$ gave $\mathrm{SF}_{6}$ values nearly identical to those measured at the same time on Ascension Island, while many samples taken north of ca. $4^{\circ} \mathrm{S}$ approached $\mathrm{SF}_{6}$ values typical of $\mathrm{NH}$ air. In the following, we will use the observed $\mathrm{SF}_{6}$ concentrations as a metric for the contributions of $\mathrm{NH}$ and $\mathrm{SH}$ air in a given sample. 

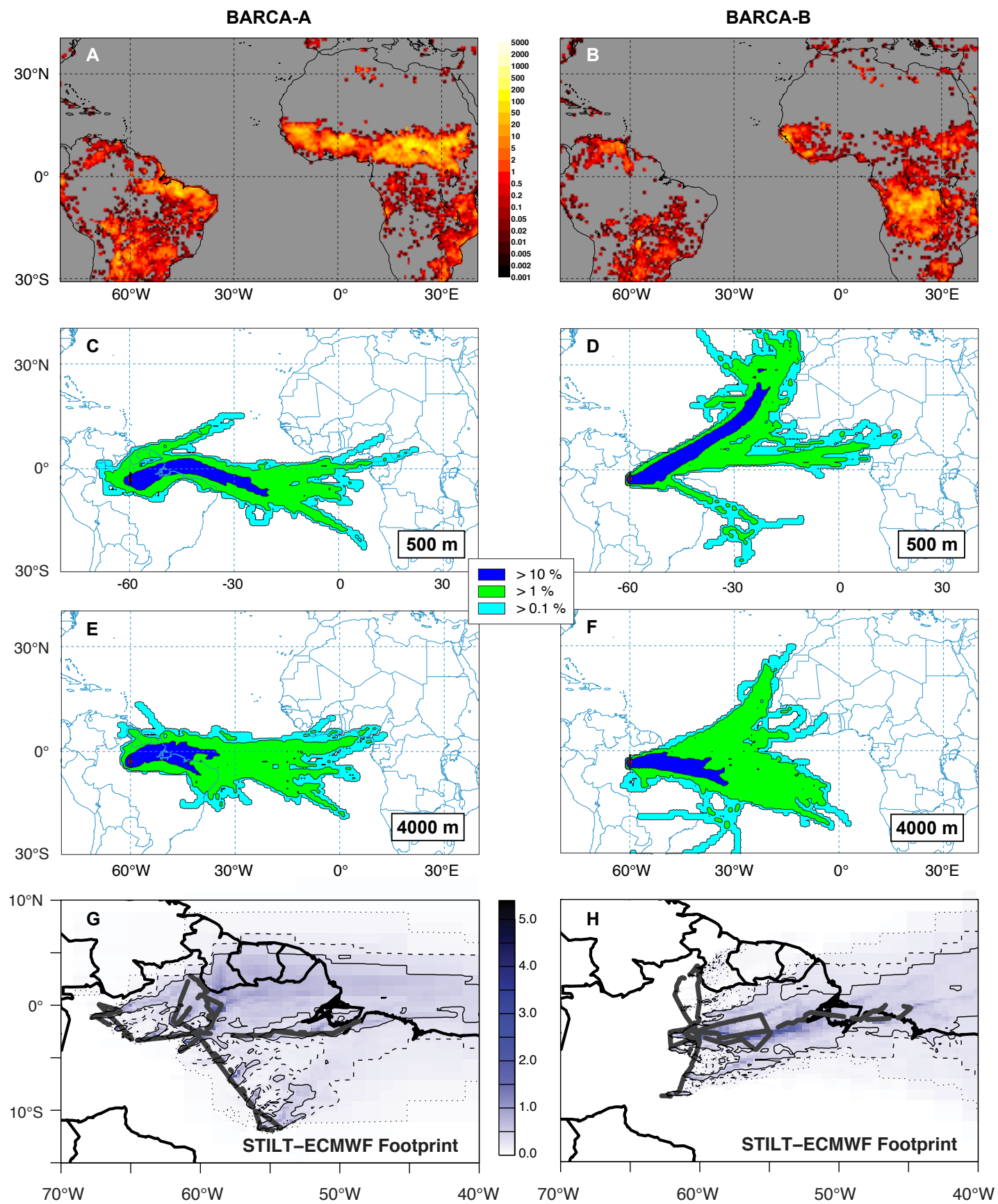

Fig. 2. The distribution of vegetation fires and atmospheric transport during BARCA-A (left) and BARCA-B (right). Panels (A) and (B) show the mean Fire Radiative Power (FRP), a proxy for the amount of biomass burned, over the campaign periods in units of $\mathrm{mW} \mathrm{m}^{-2}$. The colors in panels $(\mathbf{C}-\mathbf{F})$ indicate the frequency of trajectories passing through the corresponding areas. The colors in panels $(\mathbf{G})$ and $(\mathbf{H})$ represent the influence of surface emissions on the concentrations at the receptor site in $\mathrm{ppm} \mu \mathrm{mol}{ }^{-1} \mathrm{~m}^{2} \mathrm{~s}$.

\subsection{BARCA-A: late dry season}

The $\mathrm{CO}$ mixing ratios measured in the flask samples from BARCA-A are plotted against $\mathrm{SF}_{6}$ in Fig. 4, together with the simultaneous data from the NOAA ESRL stations. These stations are located in the remote tropical Atlantic and can be considered to represent the composition of the air flow- ing into the Amazon Basin with the trade winds. In November 2008, the CO mixing ratios were almost identical in the $\mathrm{SH}$ and NH tropics over the Atlantic (http://www.esrl.noaa. gov/gmd/ccgg/iadv/). On both sides of the equator, the concentrations of $\mathrm{CO}$ are near the mid-level of their seasonal cycles, and the average mixing ratios at ASC (72 ppb) and ABP ( $85 \mathrm{ppb})$ are elevated by about $10-30 \mathrm{ppb}$ above the 

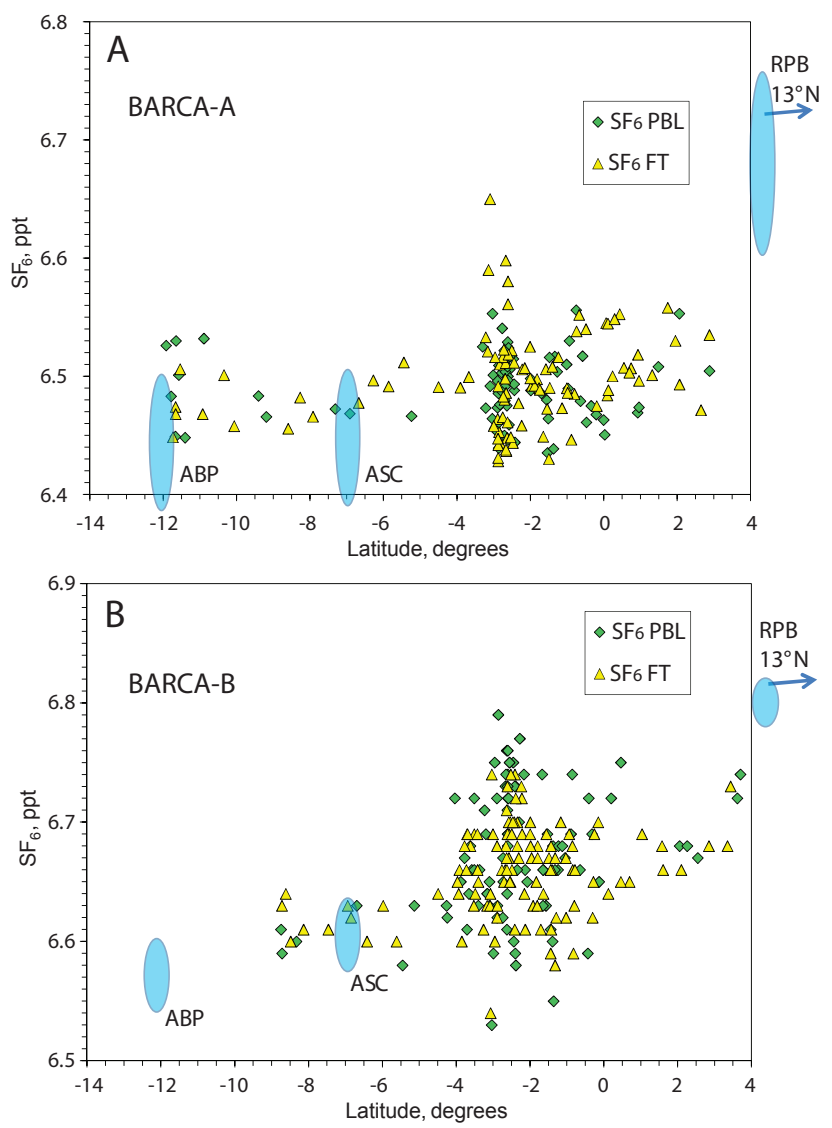

Fig. 3. Mixing ratios of sulfur hexafluoride $\left(\mathrm{SF}_{6}\right)$ versus latitude, measured in flask samples taken during BARCA-A (A) and BARCA-B (B). The values obtained simultaneously at the NOAA monitoring sites Ragged Point, Barbados (RPB), Arembepe, Brazil $(\mathrm{ABP})$, and Ascension Island (ASC) are indicated for reference.

global background (e.g., Seychelles ca. 75 ppb and Samoa ca. $57 \mathrm{ppb}$ ), as a result of biomass burning emissions in Africa. The SH air masses entering the Amazon Basin during BARCA-A therefore already carry a modest input from biomass burning, originating in Africa. If there were no additional input in the Basin, our measurements would fall into the range of mixing lines between ASC/ABP and RPB in Fig. 4a. This is, however, only the case for a relatively small number of points from the FT, while all the PBL values and most of the FT data are above the mixing line, by as much as $200 \mathrm{ppb}$, indicating large inputs of $\mathrm{CO}$ during airmass travel across the Basin.

The latitudinal distribution of $\mathrm{CO}$ in the PBL is shown in Fig. 5a, using the continuous data (1 min averages) from the airborne instrument. The low-level inflow into the Basin is represented by the large red circles for ABP, ASC, and MXR. The CO levels at these sites are almost identical, and also do not differ significantly from those at Barbados in the NH. At the northern end of the profile, the concentrations measured on the aircraft in the PBL are similar to those in the inflow,
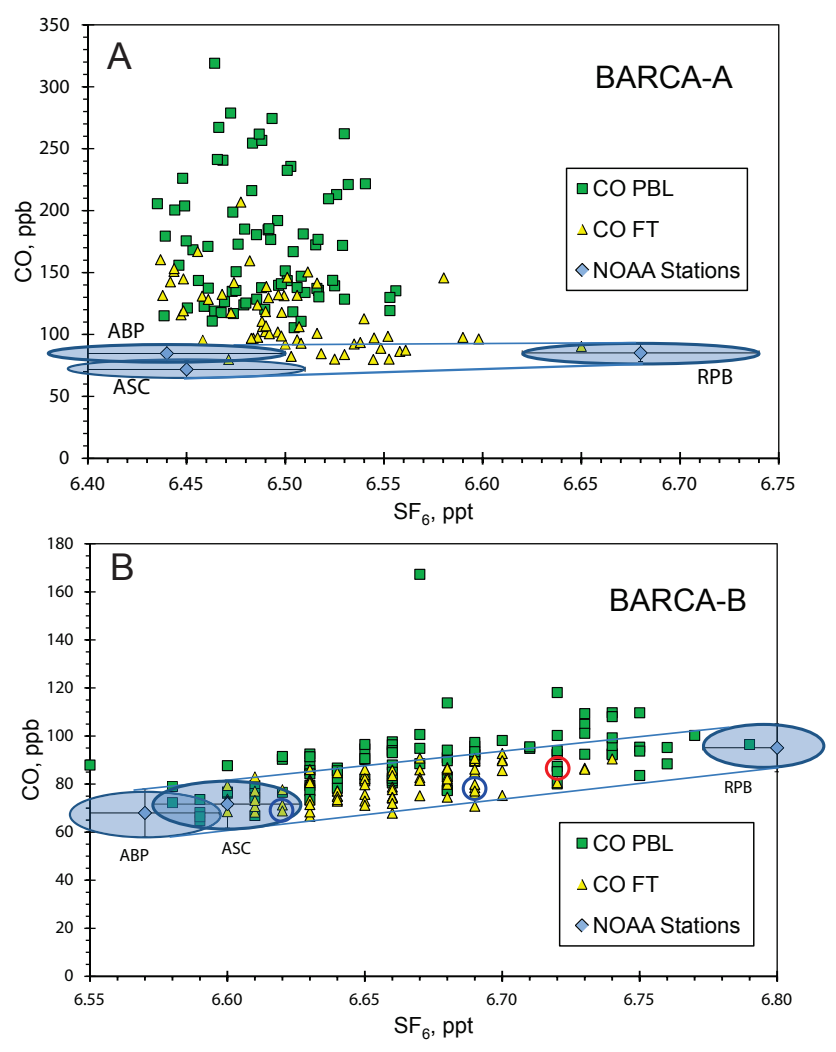

Fig. 4. Plot of CO from the flask samples against sulfur hexafluoride $\left(\mathrm{SF}_{6}\right)$, which serves as a tracer of $\mathrm{NH}$ vs. $\mathrm{SH}$ airmass origin, for BARCA-A (A) and BARCA-B (B). The values measured simultaneously at the NOAA monitoring sites Ragged Point, Barbados (RPB), Arembepe, Brazil (ABP), and Ascension Island (ASC) are shown for reference. The red circle in panel (B) indicates a sample of PBL inflow off the Brazilian coast, the blue circles indicate samples of FT inflow.

then gradually rise to about $120 \mathrm{ppb}$ near $2^{\circ} \mathrm{S}$, followed by a sharp increase to values in the range $150-400 \mathrm{ppb}$ south of $3^{\circ} \mathrm{S}$. As we have shown above, this increase cannot be related to a boundary between $\mathrm{NH}$ and $\mathrm{SH}$ air, since the entire region is dominated by $\mathrm{SH}$ air and there is no correlation between elevated $\mathrm{CO}$ and $\mathrm{SF}_{6}$. The elevated $\mathrm{CO}$ thus represents the effect of biomass burning emissions in the eastern and southern parts of the Basin, as supported by the fire locations and trajectories shown in Fig. 2. The highest values were encountered on Flights 10-12 (25-27 November), when the aircraft flew through a region affected both by long-range transport of smoke from eastern Brazil and by emissions from some regional burning. The ground-level measurements at SAN (red circle, Fig. 5a) are in good agreement with PBL aircraft measurements in the Santarém region. In Fig. 5b we show a plot of $\mathrm{CO}$ against an estimate of the longitudinal distance from the coast (idealized by a line connecting the MXR site with Paramaribo, Suriname). The data show a large amount of variability, but suggest an increasing trend going 

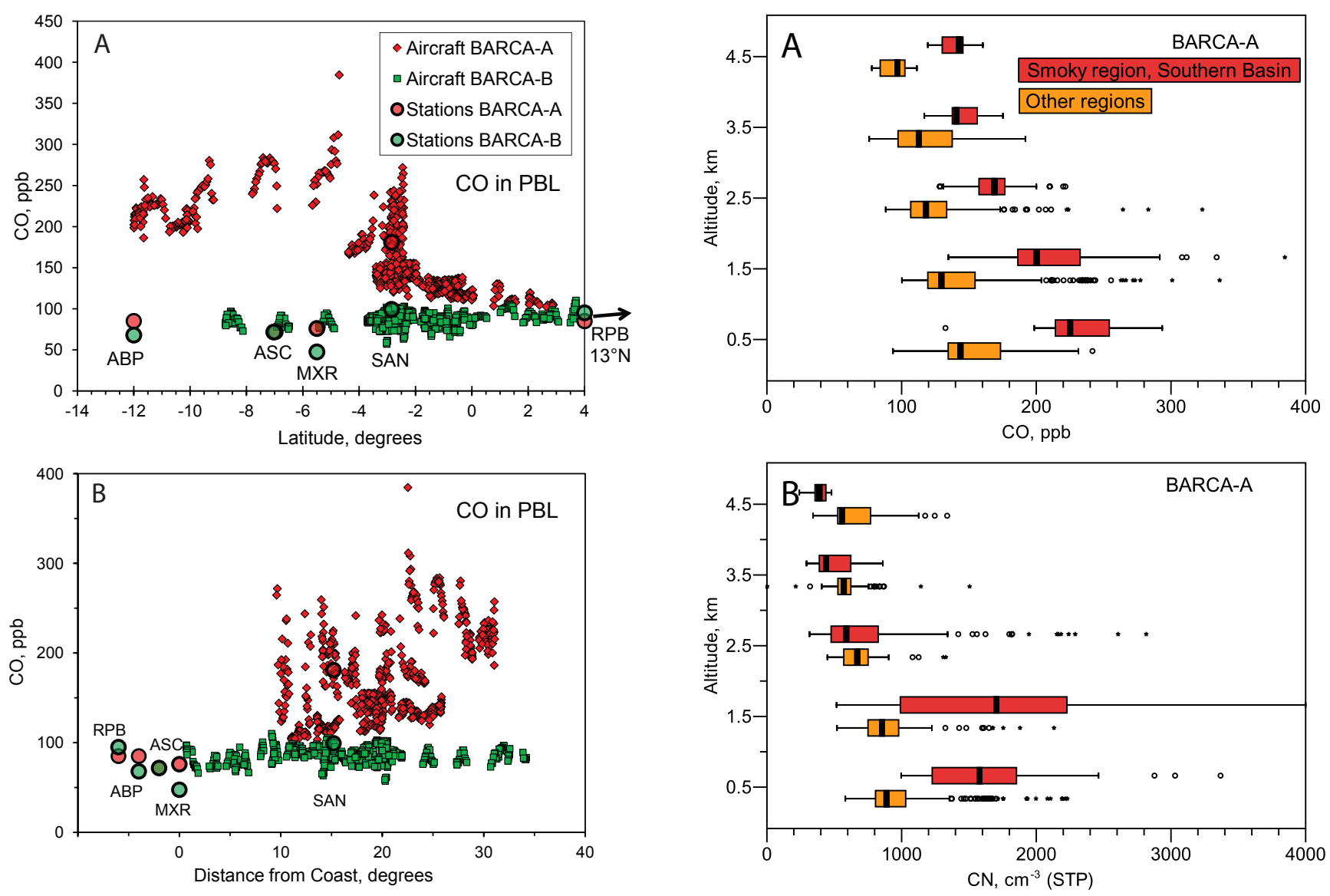

Fig. 5. Latitudinal (A) and longitudinal (B) distribution of CO during the BARCA campaigns, based on 1-min averages of the insitu measurements. Simultaneous measurements taken at the NOAA ESRL stations (RPB, ABP, and RPB) and the ground stations MXR and SAN are also shown. In (B), the longitudinal distance from the coast is calculated as the difference in longitude between the sampling location and a line connecting the MXR site with Paramaribo, Suriname, which approximates the position of the coastline.

inland, consistent with an accumulation of pyrogenic $\mathrm{CO}$ as airmasses travel across the Basin.

The vertical distributions of $\mathrm{CO}$ and aerosol particle $(\mathrm{CN})$ concentrations are shown in Fig. 6, where the data from the smoky region in the southern Basin and the other data are plotted separately. Both $\mathrm{CO}$ and $\mathrm{CN}$ are elevated in the lower parts of the profile, with the highest concentrations found at altitudes between 1 and $3 \mathrm{~km}$, typical injection heights for biomass burning in the Amazon Basin (Guyon et al., 2005; Freitas et al., 2009; Longo et al., 2009). The bar charts in Fig. 6 show a substantial number of points that lie far above the 75th percentile range; these points represent measurements in fire plumes from nearby sources or in elevated smoke layers.

Further insight into the role of biomass burning as a source of $\mathrm{CO}$ and $\mathrm{CN}$ can be obtained from a scatter plot of these variables (Fig. 7). There is a clear separation between the

more northerly flights (A07-A09, A13-A15) and the flights to the south (A10 and A11; Flight A12 gave no valid CN data). The lowest values for both $\mathrm{CO}$ and $\mathrm{CN}$ were measured on A08 and A09, near Boa Vista in the northernmost Amazon. For the flights south to Mato Grosso State (A10 and A11) two different trends can be identified in the data: individual plumes from nearby fires, and a generally smoke-polluted background in the PBL. These trends are illustrated by the black (smoke plume sampled around 13:15 UTC on Flight A10) and blue symbols (background outside the smoke plumes on A10) in Fig. 7 (the red symbols mark the remaining data from Flight A10 and A11). The smoke plume data (black) show the typical high correlation between $\mathrm{CN}$ and $\mathrm{CO}$ that has been observed in fire plumes on many campaigns (e.g., Le Canut et al., 1996; Hobbs et al., 2003; Guyon et al., 2005; Andreae and Rosenfeld, 2008; Janhäll et al., 2010; Kuhn et al., 2010). The regression slope 


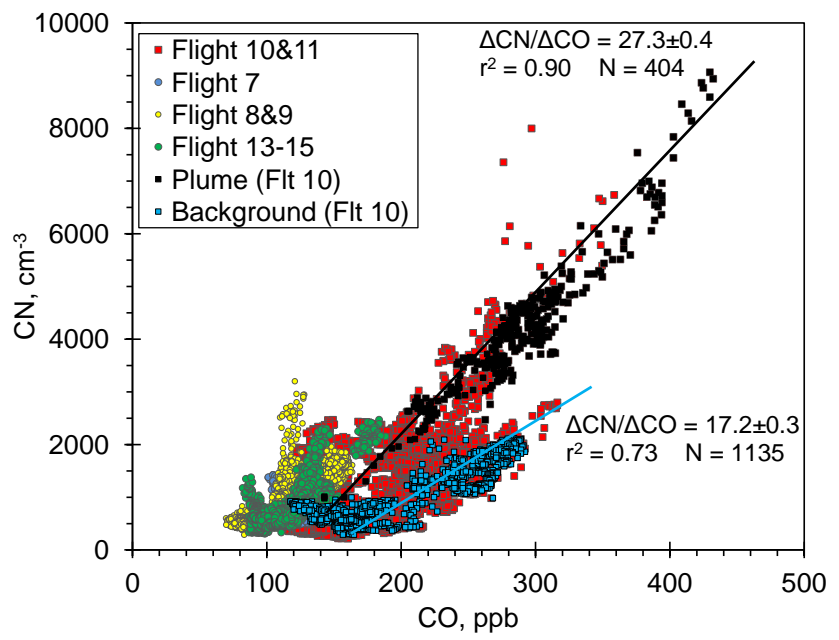

Fig. 7. Plot of aerosol particle number concentration (CN) vs. $\mathrm{CO}$ mixing ratio (2-s data) from BARCA-A.

between $\mathrm{CN}$ and $\mathrm{CO}$ corresponds to a $\Delta \mathrm{CN} / \Delta \mathrm{CO}$ ratio of $27.3 \pm 0.4 \mathrm{~cm}^{-3} \mathrm{ppb}^{-1}\left(r^{2}=0.90, N=404\right)$, close to the average value for forest fires $\left(30 \pm 15 \mathrm{~cm}^{-3} \mathrm{ppb}^{-1}\right)$ given by Janhäll et al. (2010). Given the large geographic extent of the sampling during the BARCA flights, clear $\mathrm{CN}-\mathrm{CO}$ relationships for the smoky background are more difficult to extract. As an illustrative example we show the background data from Flight A10 (blue squares). Regression analysis of the data from altitudes $<2 \mathrm{~km}$ gives a $\Delta \mathrm{CN} / \Delta \mathrm{CO}$ ratio of $17.2 \pm 0.3 \mathrm{~cm}^{-3} \mathrm{ppb}^{-1}\left(r^{2}=0.73, N=1135\right)$, similar to previous results in aged smoke, and consistent with some loss of particles by coagulation and other processes during aging (Andreae et al., 1994; Browell et al., 1996). It is difficult to derive regression slopes from the regional data from the northerly flights, but an overall trend similar to the one indicated for the background on A10 may also apply for these data (blue, green and yellow circles on Fig. 7). The $\Delta \mathrm{CN} / \Delta \mathrm{CO}$ and $\Delta \mathrm{CO} / \Delta \mathrm{CO}_{2}$ emission ratios measured on individual fire plumes will be discussed in more detail below.

\subsection{BARCA-B: late wet season}

The great seasonal contrast in the behavior of $\mathrm{CO}$ over Amazonia is clearly seen in Figs. 4 and 5. While during BARCAA the Basin atmosphere was dominated by SH air that was receiving large inputs of $\mathrm{CO}$ from sources within the Basin, during BARCA-B roughly equal amounts of $\mathrm{NH}$ and $\mathrm{SH}$ air were present, with only small within-basin inputs showing as deviations from the mixing line (Fig. 4b). The aircraft sampled the inflow into the Basin only in one instance, on 22 May at a point off the coast east of Belém (see Fig. 1). This point (indicated by a red circle in Fig. 4b) falls right on the RPBASC mixing line, and both composition and trajectory calculations indicate a dominant $\mathrm{NH}$ origin of air within the PBL near the equator. Some of the air entering the Basin in the FT (blue circles in Fig. 4b), on the other hand, showed more $\mathrm{SH}$ influence. The sample with $6.69 \mathrm{ppb} \mathrm{SF}_{6}$ was taken at $0.3^{\circ} \mathrm{S}$, and the airmass back-trajectory follows closely along the equator for the preceding 9 days. In contrast, the sample with $6.62 \mathrm{ppb} \mathrm{SF}_{6}$, which was collected only $135 \mathrm{~km}$ away at $1.3^{\circ} \mathrm{S}$, has a back-trajectory that moves rapidly to the southeast and ends up near $20^{\circ} \mathrm{S}$ after 9 days. This example provides a striking illustration of how highly diverse airmasses may be encountered in close proximity in the ITCZ region, and how well they can be distinguished both by the $\mathrm{SF}_{6}$ tracer and by trajectory analysis.

As is expected during the wet season, there were few detectable fires in the Amazon Basin during the BARCA-B period (Fig. 2b). Consequently, the $\mathrm{CO}$ levels during this period were much lower than during BARCA-A (Fig. 4). The FT air samples all fall within the mixing band between the $\mathrm{NH}$ and SH Atlantic NOAA stations, while some of the PBL samples are elevated above the mixing band. We quantify this "excess CO" as the difference between the measured value and the mixing line connecting ASC, ABP and RPB. For the FT data, the mean excess $\mathrm{CO}$ is not significantly different from zero $(0.7 \mathrm{ppb})$, suggesting the absence of a measurement bias between our data and the NOAA ESRL measurements. The median excess $\mathrm{CO}$ in the PBL is $8.8 \mathrm{ppb}$ (quartile range 3.2$14.8 \mathrm{ppb}$ ), reflecting the influence of a small, but significant net input of CO into the Amazon PBL, on the order of $10 \%$ of the background value. This net input is the sum of the photochemical loss of $\mathrm{CO}$ during its travel from the reference sites and the inputs from biomass and fossil fuel burning, photochemical production from $\mathrm{CH}_{4}$ and VOCs, and possible biological metabolic emissions. We will examine the lateral and vertical gradients as well as the relationship of CO to $\mathrm{CN}$ for indications about the role of these sources and sinks.

The latitudinal distribution of $\mathrm{CO}$ in the PBL during BARCA-B displays only a very slight increasing gradient from south to north (Fig. 5a), in close agreement with the ground-level measurements at the NOAA monitoring sites (large green circles in Fig. 5a and b), which show only a small difference between RPB and ABP or ASC. At MXR, significantly lower concentrations were measured during BARCA$\mathrm{B}$ than at the other $\mathrm{SH}$ sites and on the aircraft; this difference is yet unexplained. The plot of $\mathrm{CO}$ vs. the distance from the coast (Fig. 5b) shows no clearly detectable increase with the distance traveled across the Amazon Forest. The difference between the measurements from interior points in BARCA$B$ versus coastal and marine sites suggests an increase from $\sim 70 \mathrm{ppb}$ offshore to $\sim 80 \mathrm{ppb}$ inshore. There is a suggestion of a further increase to values around $90-100 \mathrm{ppb}$ by around $15^{\circ}$ longitudinal distance from the coast, but no evidence of a further growth in $\mathrm{CO}$ concentrations further into the Basin. Given the variability of the data during this campaign, we do not find clear evidence that the net effect of biological and photochemical sources and sinks of $\mathrm{CO}$ produces a distinct gradient during airmass transport. 

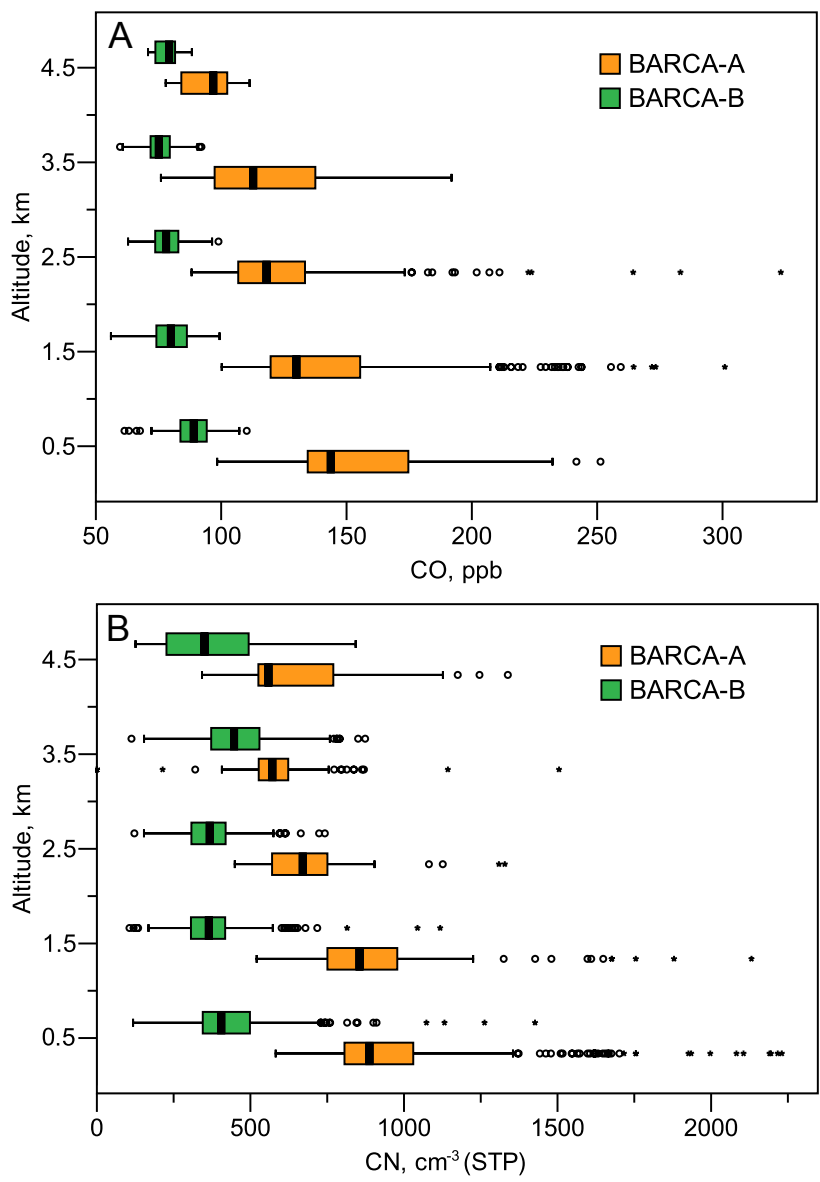

Fig. 8. Vertical profiles of $\mathrm{CO}$ mixing ratios (A) and $\mathrm{CN}$ number concentrations (B) during BARCA-A (excluding the smoky region) and BARCA-B. The center line in the bar-and-whisker plots represents the medians, the boxes show the upper and lower quartiles, the whiskers show the expected range, and the symbols represent outliers and extreme values (as defined by SPSS).

In contrast to the observations from the late dry season, there is only a slight vertical gradient in $\mathrm{CO}$ and no detectable vertical structure in $\mathrm{CN}$ concentrations during the wet season (Fig. 8). The mean CO mixing ratio of $89.0 \pm 7.6 \mathrm{ppb}$ in the layer below $1 \mathrm{~km}$ is significantly higher than that above $1 \mathrm{~km}, 77.5 \pm 6.6 \mathrm{ppb}$. Differential advection of $\mathrm{SH}$ and $\mathrm{NH}$ air at different altitudes can be ruled out as a cause for this gradient, because the $\mathrm{CO}$ mixing ratio gradient between $\mathrm{PBL}$ and FT has no associated gradient for $\mathrm{SF}_{6}$ (Fig. 4b). Biomass burning is also not a likely cause of the PBL CO enhancement during BARCA-B, as there is no overall statistically significant relationship between $\mathrm{CN}$ and $\mathrm{CO}$ in the PBL during BARCA-B. There are a few (6) data points with both elevated $\mathrm{CO}$ and $\mathrm{CN}$ that may be related to local burning activities or urban sources, but when these data points (with $\mathrm{CN}>800 \mathrm{~cm}^{-3}$ ) are removed, the $<1-\mathrm{km}$ mean only drops to $88.9 \pm 7.5$, indicating that biomass burning or other anthropogenic sources such as urban emissions in the Basin did not
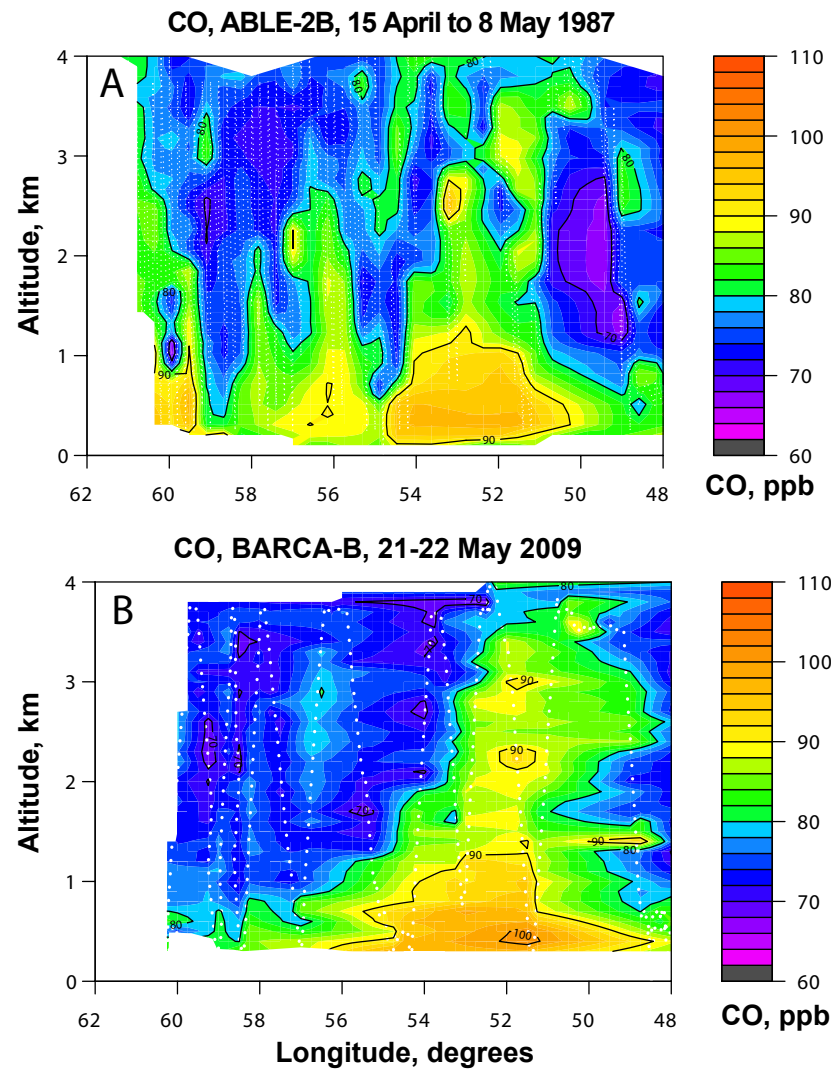

Fig. 9. Cross sections of CO mixing ratios from (A) ABLE-2B (15 April-8 May 1987) and (B) BARCA-B (21-22 May 2009) along the equator $\left( \pm 4^{\circ}\right)$. Urban data and a fresh smoke plume were omitted from the data. White dashed lines show flight tracks.

significantly contribute to $\mathrm{CO}$ levels. The $\mathrm{CO}$ vertical gradient (enhancement in the PBL) is thus most likely related to inputs from VOC oxidation or from biological emissions, which are too small to show up as a longitudinal gradient.

During the ABLE-2B mission (April-May 1987), enhanced concentrations of $\mathrm{CO}$ had also been observed in the PBL during the wet season (Harriss et al., 1990b), and in the canopy space of the Amazon rainforest (Kirchhoff and Marinho, 1990). Similar enhancements were seen during the LBA-CLAIRE-98 aircraft campaign over the northern Amazon rainforest in Suriname (Williams et al., 2001). Most of this excess CO is likely the product of the photo-oxidation of isoprene and other VOCs, but a metabolic contribution from the ecosystem, especially decaying plant matter, is suggested by the observed enrichment near the ground (Kirchhoff and Marinho, 1990) and by laboratory experiments showing CO production by thermal and photochemical degradation of plant matter and soil organic matter (Conrad and Seiler, 1985; Schade and Crutzen, 1999; Schade et al., 1999). The production of CO by living plants may also play a role (Seiler et al., 1978; Bauer et al., 1979; Tarr et al., 1995). 

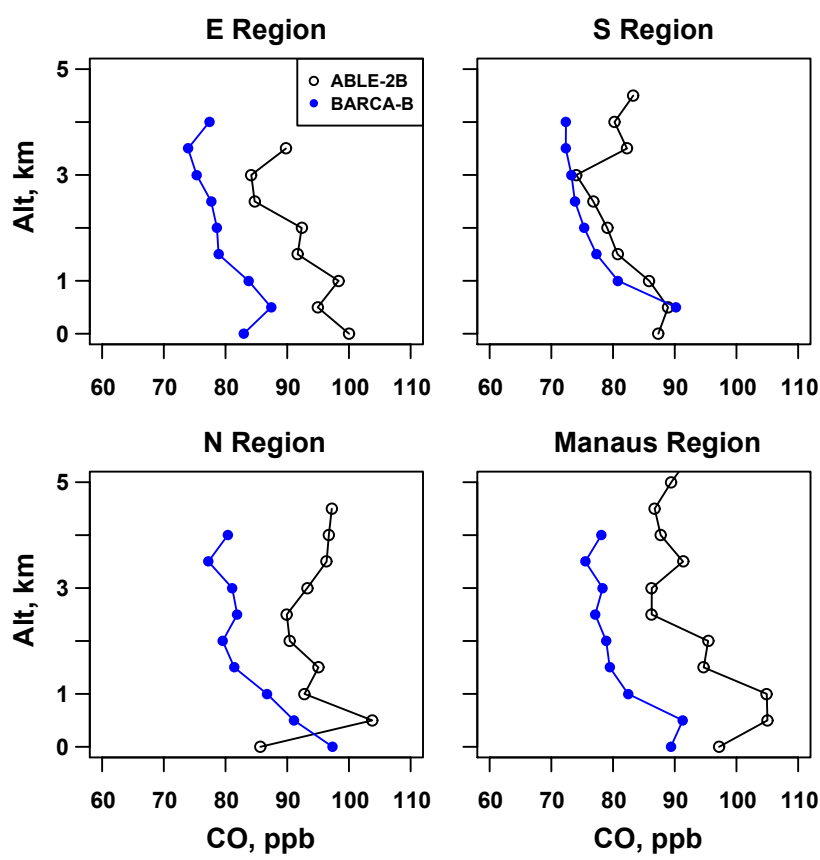

Fig. 10. Comparisons of median vertical profiles for the Equatorial Transect east of Manaus ("E. Region"), N and S transects along $60^{\circ} \mathrm{W}$ longitude, and near Manaus (excluding local pollution). Note the strong similarities between ABLE-2B and BARCA-B data taken more than 20 years apart. (Source of ABLE data: Harriss et al., 1990b).

Comparison of E-W cross-sections (Fig. 9) and vertical profiles (Fig. 10) from BARCA-B (May 2009) and ABLE2B (April-May 1987) reveal interesting similarities and differences. The $\mathrm{CO}$ mixing ratios from ABLE-2B are notably higher, by about $10 \mathrm{ppb}$, everywhere except the southern region. This difference is consistent with the long term trends in CO. Global CO concentrations peaked in the late 1980s, followed by a decline through the 1990s and relatively stable levels through the 2000s. The most pronounced decline was in the $\mathrm{NH}$, apparently related to emission reductions in N. America and Europe (Novelli et al., 2003; Duncan and Logan, 2008). The observed 2009-1987 difference of about $10 \mathrm{ppb}$ in northerly tropical regions, and the near-identical values in the southerly region, closely match the trends observed by the global monitoring networks in the $\mathrm{NH}$ and $\mathrm{SH}$ tropics, respectively (Duncan and Logan, 2008).

In contrast to the BARCA-B data, the ABLE-2B measurements show a pronounced east-west gradient (Fig. 9). This difference appears to reflect notably stronger NH influence in the Central Amazon during the 1987 flights. Trajectory analyses show that the region around $60^{\circ} \mathrm{W}$ (western end of the section in Fig. 9) received $\mathrm{NH}$ airmasses during all of ABLE-2B, while the area around $48^{\circ} \mathrm{W}$ was under $\mathrm{SH}$ airmasses during all of April and most of May 1987. At the time of ABLE-2B, there was a pronounced difference in the hemispheric $\mathrm{CO}$ background, with values around $110 \mathrm{ppb}$ in
$\mathrm{NH}$ airmasses and around $80 \mathrm{ppb}$ in $\mathrm{SH}$ air. Advection of $\mathrm{NH}$ airmasses into the central Amazon Basin thus led to the increased $\mathrm{CO}$ levels in the central and western Basin during ABLE-2B (Harriss et al., 1990b). These observations underscore the point that atmospheric composition and processes in the Amazon Basin cannot be understood without the consideration of pollutant inputs by long-range transport. Gaseous pollutants are present in the atmosphere of Amazonia in the wet season, even when wet processes efficiently scrub out aerosol components. The Amazon atmosphere cannot be considered "pristine" (unaffected by human activity) even in the wet season when regional biomass fires are largely absent.

The two campaigns, ABLE-2B and BARCA-B, show striking similarity in the vertical gradient of the $\mathrm{CO}$ mixing ratios, with an increase of $10-20 \mathrm{ppb}$ in the lowest $1-2 \mathrm{~km}$ of the profile in all regions (Fig. 10). This consistency for wet season missions more than $20 \mathrm{yr}$ apart reinforces the view that natural processes yield diffuse photochemical/biogenic sources of CO during the wet season. It also implies that the enhancements in the dry season ( $\gg 10-20 \mathrm{ppb}$ ) cannot be explained by biogenic sources and must be related to anthropogenic processes, particularly to biomass burning.

\subsection{Emission characteristics of $\mathrm{CO}_{2}, \mathrm{CO}$, and $\mathrm{CN}$ from biomass and fossil fuel combustion}

Since the BARCA campaigns rarely sampled fresh emissions from biomass and fossil fuel combustion, only a few measurements can be used to derive emission factors or emission ratios. On the other hand, valid estimates of the emission ratios, $\Delta \mathrm{CO} / \Delta \mathrm{CO}_{2}$, from biomass and fossil fuel combustion are essential for separating the biospheric from the combustion sources of $\mathrm{CO}_{2}$ in the Basin, which is a central objective of the BARCA project. In the following, we will combine the data obtained during BARCA with literature information to derive a reasonable range of estimates that can be used for further analysis of the Amazonian carbon and aerosol budgets.

Deriving accurate $\Delta \mathrm{CO} / \Delta \mathrm{CO}_{2}$ emission ratios (and emission ratios to $\mathrm{CO}_{2}$ in general) is a very difficult task for several reasons. First, $\mathrm{CO}_{2}$ levels in combustion plumes typically show relatively small enhancements compared to background concentrations, requiring measurements in close proximity (typically up to a few $\mathrm{km}$ ) to fires in order to determine $\mathrm{CO} / \mathrm{CO}_{2}$ emission ratios. Second, $\mathrm{CO} / \mathrm{CO}_{2}$ emission ratios can vary strongly and systematically within a given fire, with smoldering combustion having ratios up to severalfold higher than flaming combustion. Flaming and smoldering phases can be widely separated in time, especially in the case of large tree trunks which can continue smoldering for days after the main fire. Smoldering and flaming emission products are also separated spatially, as flaming emissions may be lofted hundreds or thousands of meters above the surface, while smoldering emissions can be trapped near 
Table 1. Emission ratios $\Delta \mathrm{CO} / \Delta \mathrm{CO}_{2}$ measured during the BARCA campaign flights.

\begin{tabular}{lllllll}
\hline Sample & Date & Time UTC & Altitude, $\mathrm{m}$ & $\Delta \mathrm{CO} / \Delta \mathrm{CO}_{2} \times 10^{3}$ & $r^{2}$ & $N$ \\
\hline Fire Plumes & & & & & \\
\hline A03-A & 18 Nov 08 & $15: 45$ & 900 & $55.5 \pm 7.3$ & 0.76 & 21 \\
A04-A & 18 Nov 08 & $20: 18$ & $2300-2600$ & $58.8 \pm 1.8$ & 0.94 & 59 \\
A04-B & 18 Nov 08 & $20: 26$ & 1000 & $64.4 \pm 3.2$ & 0.92 & 32 \\
A04-C & 18 Nov 08 & $20: 33$ & 250 & $63.6 \pm 11.1$ & 0.57 & 9 \\
A05-A & 19 Nov 08 & $13: 34$ & $1700-2600$ & $108.8 \pm 3.9$ & 0.85 & 129 \\
B05-A & 19 Nov 08 & $18: 21$ & 1100 & $42.7 \pm 3.8$ & 0.94 & 9 \\
\hline Average & & & $65.6 \pm 22.6$ & & \\
\hline Urban Plumes & & & & & & \\
\hline B08-B (Belem) & 22 May 09 & $16: 17$ & 270 & $15.2 \pm 0.4$ & 0.94 & 79 \\
B12-A (Manaus) & 26 May 09 & $21: 05$ & 380 & $5.9 \pm 0.4$ & 0.84 & 39 \\
B15-A (Manaus) & 28 May 09 & $20: 01$ & 650 & $5.9 \pm 0.2$ & 0.85 & 117 \\
\hline Average & & & $9.0 \pm 5.4$ & & \\
\hline
\end{tabular}

the ground, especially at night. Hence $\mathrm{CO}$ from flaming fires is more readily sampled by aircraft than $\mathrm{CO}$ from smoldering. Finally, the fact that fire emissions entrain air from the lower boundary layer, but are sampled in the FT or the upper boundary layer, can lead to strong bias in the $\Delta \mathrm{CO} / \Delta \mathrm{CO}_{2}$ ratio (Guyon et al., 2005). Early in the day, the concentrations of $\mathrm{CO}_{2}$ in the lower few $100 \mathrm{~m}$ are strongly elevated because of accumulated emissions from biological respiration overnight. Smoke that comes from a fire during this time of day thus contains excess $\mathrm{CO}$ mainly from the fire, but $\mathrm{CO}_{2}$ is elevated both from the fire and from respiration. When this smoke is lofted as a plume into the FT, and the FT concentrations of $\mathrm{CO}$ and $\mathrm{CO}_{2}$ are used to calculate $\Delta \mathrm{CO}$ and $\Delta \mathrm{CO}_{2}$, the pyrogenic $\mathrm{CO}_{2}$ in the plume is overestimated (because of the presence of an unknown amount of respiratory $\mathrm{CO}_{2}$ ), and thus $\Delta \mathrm{CO} / \Delta \mathrm{CO}_{2}$ is underestimated. Simple calculations using realistic values of $\mathrm{CO}_{2}$ for the morning-time PBL show that this underestimate can easily produce a bias of a factor of three in the enhancement ratio. Consequently, only fire plumes sampled around mid-day, when the atmosphere is well-mixed up to the sampling altitude, and with strong pyrogenic $\mathrm{CO}_{2}$ anomalies, are suitable for emission ratio measurements. Only six plumes sampled during BARCA met these criteria, yielding $\triangle \mathrm{CO} / \Delta \mathrm{CO}_{2}$ ratios for biomass fires (Table 1) averaging $(65.6 \pm 22.6) \times 10^{-3}$ mole mole $^{-1}$, in good agreement with our previous measurements in Amazonia and with literature data (see Table 2).

Given the importance of tropical deforestation fires for the global and regional emissions from biomass burning, there are surprisingly few studies of emission ratios from such fires that cover all phases of the fire. We summarize these results in Table 2 . The $\Delta \mathrm{CO} / \Delta \mathrm{CO}_{2}$ ratios from aircraft studies on tropical forest burns range from $61 \times 10^{-3}$ to $103 \times 10^{-3}$, while the ground-based studies yield a range of
$84 \times 10^{-3}$ to $126 \times 10^{-3}$. Those studies that tried to account for the smoldering-derived CO-rich smoke that spreads along the ground gave emission ratios of $90 \times 10^{-3}$ and $106 \times 10^{-3}$ (Guyon et al., 2005; Yokelson et al., 2008), and the metaanalyses by Akagi et al. (2011) and Andreae and Merlet (2001; updated 2011) recommended emission ratios of $(92 \pm 26) \times 10^{-3}$ and $(99 \pm 17) \times 10^{-3}$, respectively, for tropical forest burning.

To use these $\mathrm{CO}$ emission ratios for estimating the pyrogenic contribution to atmospheric $\mathrm{CO}_{2}$ measurements, one also needs to consider the sequence of events following emission. If one wants to estimate the pyrogenic $\mathrm{CO}_{2}$ present in an identifiable smoke plume based on the $\mathrm{CO}$ measured in this plume by aircraft, the most appropriate $\Delta \mathrm{CO} / \Delta \mathrm{CO}_{2}$ ratio would be the average of the aircraft-based data, i.e., $(79 \pm 14) \times 10^{-3}$. On the other hand, the $\Delta \mathrm{CO} / \Delta \mathrm{CO}_{2}$ ratios at the ground during and immediately following the fires are so variable that a meaningful estimate is not possible, but the ratio certainly would be well in excess of $120 \times 10^{-3}$. Within a day after the fire, however, convection will mix both nearground and lofted emissions through the lower few $\mathrm{km}$ of the troposphere, and therefore a value of about $100 \times 10^{-3}$ would likely be the best estimate for the ratio of $\mathrm{CO}$ to $\mathrm{CO}_{2}$ that has been contributed by fires to the regional enhancements of both gases.

BARCA flights also provided an opportunity to determine $\triangle \mathrm{CN} / \triangle \mathrm{CO}$ emission ratios from a number of fires, mostly during the flights A10 and A11 to Mato Grosso State. A total of 9 plumes yielded useful data, for an overall average of $53 \pm 22 \mathrm{~cm}^{-3} \mathrm{ppb}^{-1}$ (Table 3). This value is somewhat higher than the global average for forest fires $\left(30 \pm 15 \mathrm{~cm}^{-3} \mathrm{ppb}^{-1}\right)$ given by Janhäll et al. (2010), but falls within the range we have previously observed in Amazonia, e.g., $50 \pm 9 \mathrm{~cm}^{-3} \mathrm{ppb}^{-1}$ in the Manaus region (Kuhn et al., 
Table 2. Comparison of emission ratios $\Delta \mathrm{CO} / \Delta \mathrm{CO}_{2}$ measured during BARCA with literature data.

\begin{tabular}{lllll}
\hline Region & Vegetation & Platform & $\Delta \mathrm{CO} / \Delta \mathrm{CO}_{2} \times 10^{3}$ & Reference \\
\hline Eastern \& Central Amazon & Mostly rainforest & Aircraft & $66 \pm 23$ & This study \\
Southern Amazon & Rainforest and some pasture & Aircraft & $61 \pm 17$ & Guyon et al. (2005) \\
Manaus region & Unknown & Aircraft & $77 \pm 40$ & Kuhn et al. (2010) \\
Central Amazon & Mostly rainforest & Aircraft & $85 \pm 4$ & Andreae et al. (1988) \\
Amazon & Rainforest & Aircraft & $103 \pm 8$ & Ferek et al. (1998) \\
Southern Amazon & Rainforest & Aircraft & $85 \pm 29$ & Ward et al. (1991) \\
Yucatan & Rainforest & Aircraft & $78 \pm 13$ & Yokelson et al. (2009) \\
Southern Amazon & Rainforest and some pasture & Aircraft, RSC corrected & $90 \pm 25$ & Guyon et al. (2005) \\
Southern Amazon & Rainforest & Aircraft and ground & 106 & Yokelson et al. (2008) \\
Southern Amazon & Pasture maintenance & Aircraft and ground & 159 & Yokelson et al. (2008) \\
Amazon & Forest & Aircraft and ground & 82 & Babbitt et al. (1996) \\
Amazon & Rainforest & Ground & 119 & Greenberg et al. (1984) \\
Southern Amazon & Rainforest & Ground & $110 \pm 51$ & Soares Neto et al. (2009) \\
Eastern Amazon & Rainforest & Ground & 126 & Ward et al. (1992) \\
Eastern Amazon & Secondary forest & Ground & 84 & Ward et al. (1992) \\
India & Dry Tropical Forest & Ground & 124 & Prasad et al. (2000) \\
Literature survey & Tropical Forest & & $92 \pm 26$ & Akagi et al. (2011) \\
Literature survey & Tropical Forest & & $99 \pm 17$ & Andreae and Merlet (2001), \\
& & & & updated 2011 \\
\hline
\end{tabular}

2010). The somewhat higher values in our recent studies are also due in part to a choice in regression algorithm. In this study and in Kuhn et al. (2010), we used the bivariate regression technique (Cantrell, 2008), which is more appropriate for data in which both predictor and response variables have unattributed variance, whereas most previous work used simple linear regression. Had we used the latter approach, we would have obtained a mean slope of $47 \pm 21 \mathrm{~cm}^{-3} \mathrm{ppb}^{-1}$ instead of $53 \pm 22 \mathrm{~cm}^{-3} \mathrm{ppb}^{-1}$.

While the BARCA campaign was not designed to study urban plumes, some of the aircraft's arrivals and departures from the tropical cities of the Amazon Basin (Manaus, Belem, and Santarem) penetrated the urban pollution plumes. The enhancement ratios $\Delta \mathrm{CO} / \Delta \mathrm{CO}_{2}$ and $\Delta \mathrm{CN} / \Delta \mathrm{CO}$ that could be obtained from these plume transits are given in Tables 1 and 3 . They are clearly different from those found in the biomass burning plumes. The $\Delta \mathrm{CO} / \Delta \mathrm{CO}_{2}$ ratio in the urban plumes is much lower, $(9.0 \pm 5.4) \times 10^{-3}$, consistent with the much more efficient combustion in power plants and automobile engines. This average is in close agreement with the value of $(11.3 \pm 10.9) \times 10^{-3}$ obtained in 2001 from a detailed investigation of the Manaus plume (Kuhn et al., 2010) and with studies on North American urban plumes (Potosnak et al., 1999), and probably reflects mixtures of varying proportions of power plant, vehicular and wood burning emissions. The mean particle number enhancement ratio, $\triangle \mathrm{CN} / \triangle \mathrm{CO}$, measured on four urban plume transects during BARCA ( $325 \pm 115$; Table 3 ), is also similar to our previous results from Manaus $(339 \pm 225)$. These high ratios are the result of high rates of particle production from urban precursors, especially $\mathrm{SO}_{2}$, combined with low $\mathrm{CO}$ emissions from relatively efficient combustion of fossil fuels.

\subsection{Model simulations of $\mathrm{CO}$ distribution}

Most of the models we have used to simulate $\mathrm{CO}$ during BARCA-A capture at least some of the features of the observed mixing ratios, including the general levels of $\mathrm{CO}$ enhancement and regional variations (Fig. 11). The dominant source regions related to biomass burning emissions in the eastern and southern part of the Amazon appear to be reflected in the source inventories, as indicated by the computed $\mathrm{CO}$ enhancements in the southern and eastern regions. On average the high-resolution simulations slightly overestimate the $\mathrm{CO}$ mixing ratios by $13 \mathrm{ppb}$, ranging from $-11 \mathrm{ppb}$ to $27 \mathrm{ppb}$. The low-resolution GEMS reanalysis product $\left(1.125^{\circ}\right.$ resolution) fails to capture most of the $\mathrm{CO}$ enhancement in the eastern part, and strongly underestimates the enhancement in the southern part, leading to an overall underestimation of $\mathrm{CO}$ by $17 \mathrm{ppb}$.

According to the tagged tracer runs using the two STILT and the two WRF-GHG simulations, biomass burning emissions contribute about $31 \%$ of the CO signal, advection of the lateral boundary condition (LBC, i.e., the large-scale background from the GEMS reanalysis, averaging $110 \mathrm{ppb}$ ) amounts to $61 \%$, while fossil fuel emissions contribute a negligible amount of less than $1 \%$. At the same time, biomass burning emissions contribute more than $95 \%$ to the variability of simulated $\mathrm{CO}$ (measured as standard deviations of the tagged tracers), indicating that biomass burning clearly dominates the spatio-temporal distribution over the Amazon.

Simulated CO during the northern and western transects from all models shows higher than observed mixing ratios, indicating an overestimation of the $\mathrm{CO}$ background concentration. The tagged tracer simulations allow a closer look 

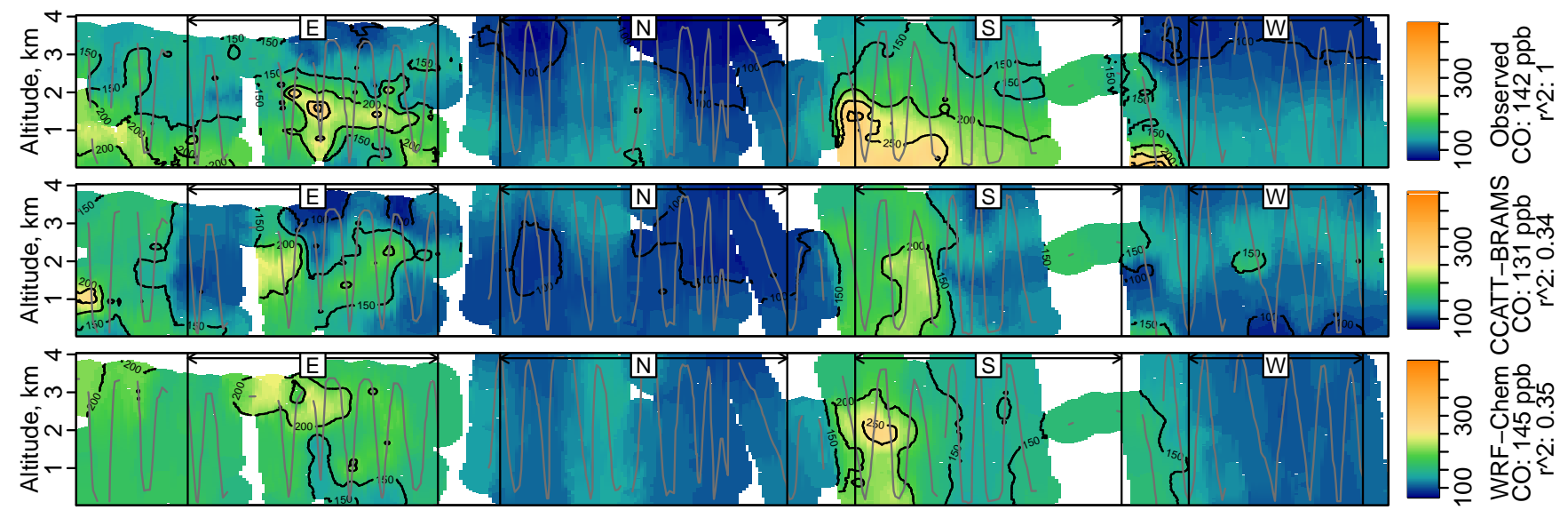

$\mathrm{W}$
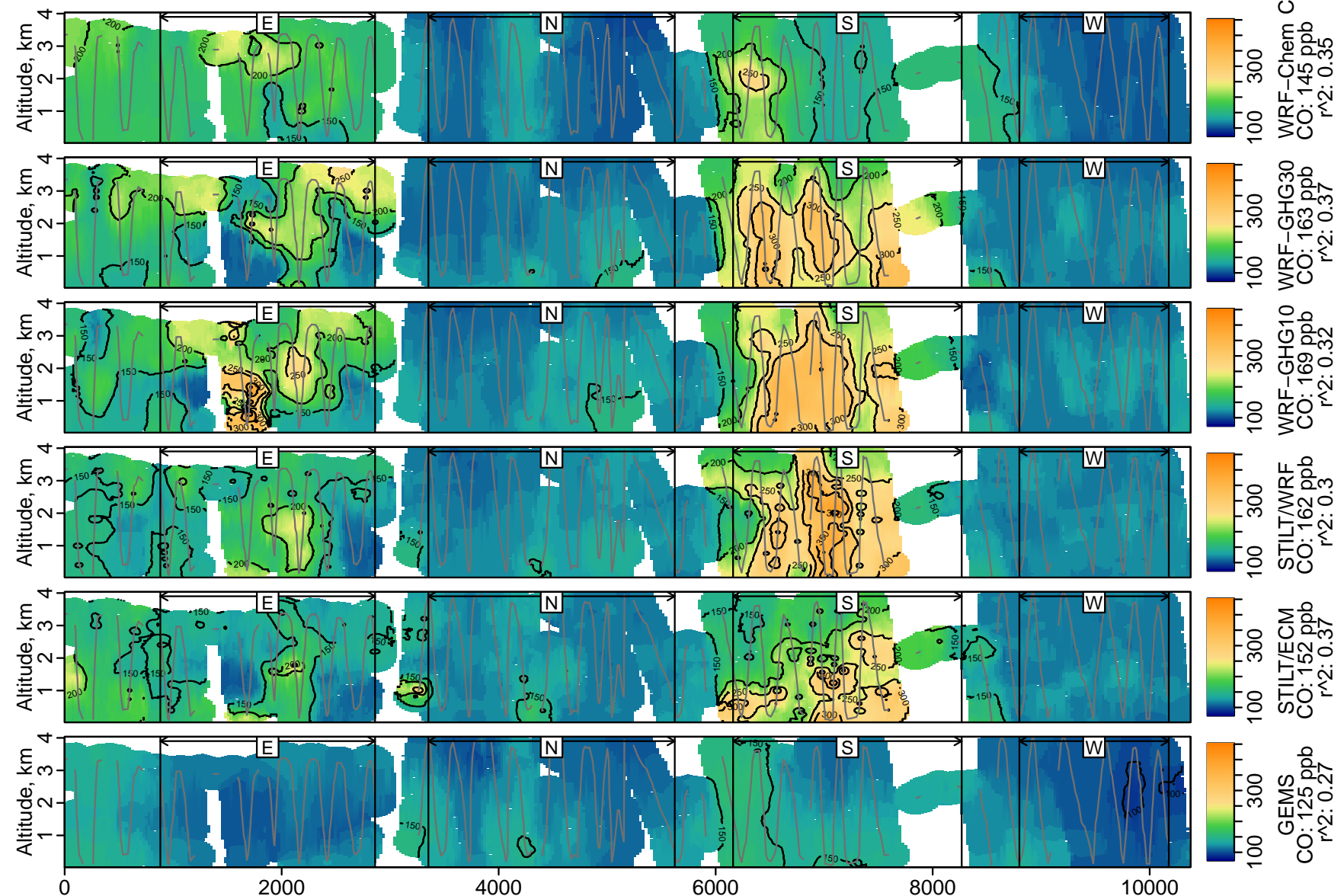

6000
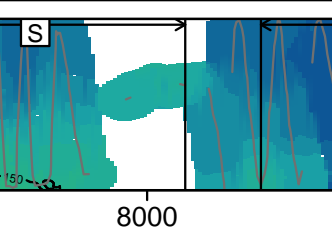

W-
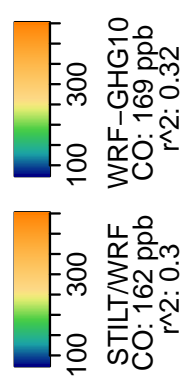

Fig. 11. Measured and modeled $\mathrm{CO}$ from various models along the flight track in units of ppb during BARCA-A. Shown are mixing ratios as function of altitude and cumulative distance flown by the aircraft, interpolated from the various vertical profile measurements using inverse distance weighting. From top to bottom: Observed CO, and modeled CO from CCATT-BRAMS, WRF-Chem, WRF-GHG (30 km), WRFGHG (10 km), STILT-WRF, STILT-ECMWF, and from the GEMS-reanalysis. The different geographical parts (E, N, S, W) of the campaign are indicated at the top of each color plot; unmarked periods are within $200 \mathrm{~km}$ of Manaus. Also shown to the right of the color legend are the averaged mixing ratios and the squared correlation coefficients between modeled and observed CO.

at the contribution from advection of the LBC during periods with low $(<15 \mathrm{ppb})$ simulated contribution from biomass burning, which reveals a model/observation difference of $19 \mathrm{ppb}$. A possible reason for this bias in WRF-GHG and STILT simulations is the missing photochemical loss (CO was treated as a conserved tracer), but it is also possible that there is a slight bias in the GEMS reanalysis CO fields used as the outer boundary. If we assume that this bias is represen- tative also for periods with a larger biomass burning contribution, we can correct for it and obtain a remaining model/data mismatch ranging from $10 \mathrm{ppb}$ underestimation for STILTECMWF to $7 \mathrm{ppb}$ overestimation for WRF-GHG at $10 \mathrm{~km}$ resolution, with an average over the STILT and WRF-GHG simulations of less than $1 \mathrm{ppb}$. Given an average contribution of $50 \mathrm{ppb} \mathrm{CO}$ from biomass burning, this is an excellent agreement. It clearly shows that the 3BEM emissions are 

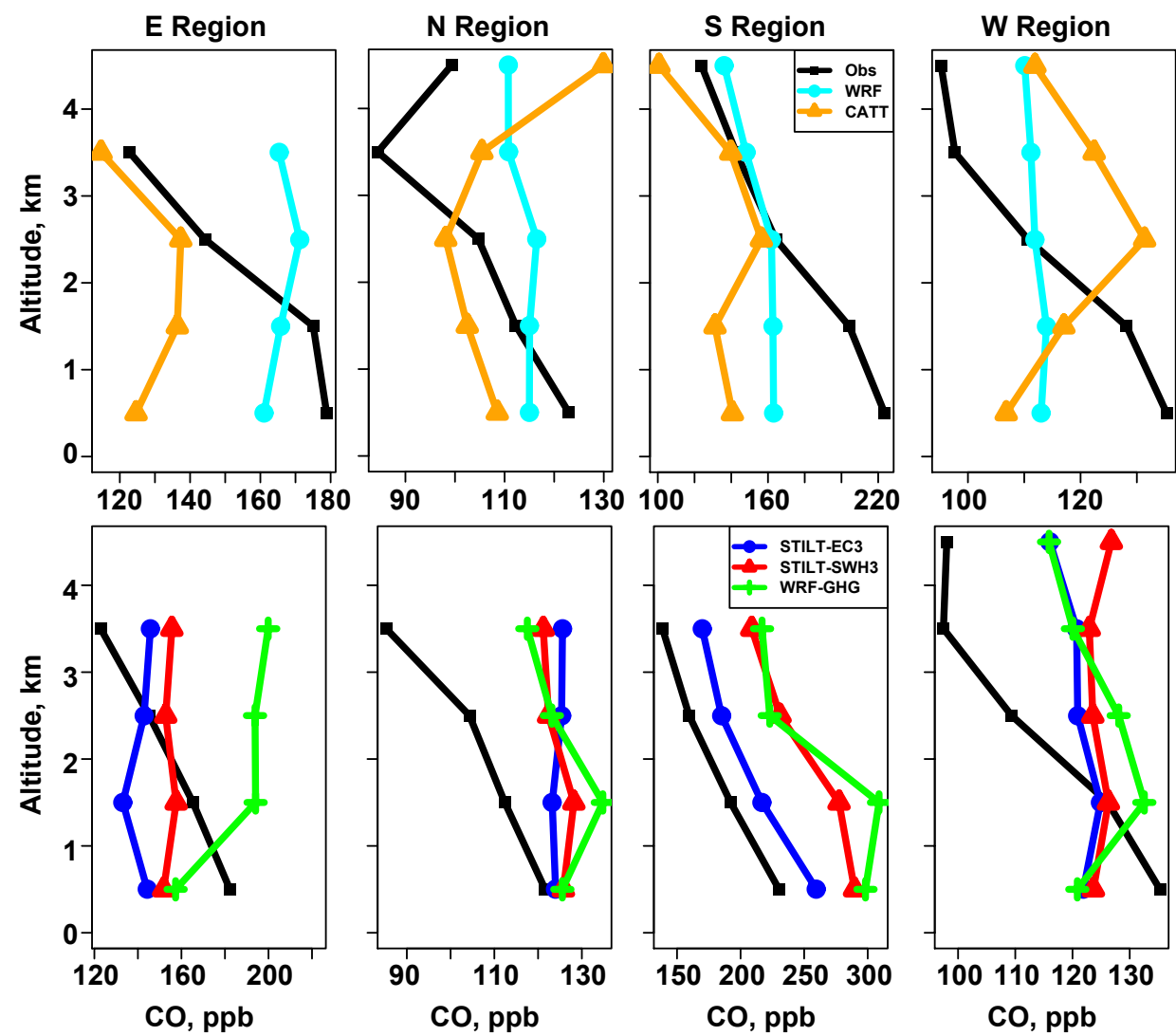

Fig. 12. Vertical profiles (regional medians, $1000 \mathrm{~m}$ blocks) for CO for high resolution models, compared to observations. Data are disaggregated by region ( $\mathrm{E}$ and $\mathrm{W}$ of Manaus, within $4^{\circ}$ of the Equator, and $\mathrm{N}$ and $\mathrm{S}$ of Manaus, roughly on the $60^{\circ} \mathrm{W}$ meridian; the region influenced by Manaus was excluded.) The upper panel shows the INPE model results (CATT-BRAMS and WRF-Chem). The lower panel shows the Jena models (the STILT Lagrangian framework with two different assimilated meteorological fields, and one Eulerian WRF model), all with CO treated as a passive tracer. Data acquired in areas influenced by local pollution (e.g., near airports and in localized smoke plumes) were excluded, comprising $\sim 15 \%$ of data points. Differences in observed values between upper and lower panels are the result of different averaging procedures required to match the observations to the model grids.

fully consistent with the BARCA-A observations, and that the observed model/observation mismatch in regional mean concentrations is mostly due to a bias in the lateral boundary condition.

Figures 12 and 13 suggest that there may be major issues with simulations of vertical transport of $\mathrm{CO}$ from biomass burning source regions into the core of the Amazon Basin. The models generally fail to simulate the observed vertical gradients (see Fig. 12), an important feature of the CO distribution and of photochemical chemistry-transport models for key pollutants (e.g., $\mathrm{NO}_{\mathrm{x}}$ ). Our data show that significant elevations of $\mathrm{CO}$ persist near the surface, even at a far distance from the main burning regions, but models almost never show this trend. The models in general do reasonably well at simulating the width and shape of the probability density of CO in the boundary layer (Fig. 13), hence overall horizontal dispersion rates may be well simulated. The models appear to be overly diffusive in the vertical and/or to have too much convective redistribution. If confirmed by detailed analysis, this result would imply important deficiencies that need to be addressed in order to use this type of model for studying atmospheric chemistry and climate.

A complicating factor is the elevated injection height of the biomass burning emissions, which leads to an addition of fire-emitted $\mathrm{CO}$ at higher altitudes. Injection altitude is believed to depend on the sensible and latent heat provided by the fire. A plume rise mechanism is incorporated in the Eulerian simulations (CCATT-BRAMS, WRF-GHG, WRFChem), but not in STILT simulations. Sensitivity analysis using WRF-GHG at $10 \mathrm{~km}$ resolution with a disabled plume rise mechanism (not shown) indicates a lowering of the $\mathrm{CO}$ contribution from biomass burning along the BARCAA flight path by $41 \%$. A similar experiment using "excessive" plume rise in STILT-ECMWF (not shown) by adding all fire related $\mathrm{CO}$ at an altitude of $2 \mathrm{~km}$ above ground (the typical altitude of plume rise in the WRF-GHG simulation) indicated an increase of $19 \%$ in CO from biomass burning. As total emissions are unaffected by plume rise, the increase 
Table 3. Emission ratios $\Delta \mathrm{CN} / \Delta \mathrm{CO}$ measured during the BARCA campaign flights. The error values given for the individual plumes represent standard errors, while for the averages standard deviations are given.

\begin{tabular}{|c|c|c|c|c|c|c|}
\hline Sample & Date & Time UTC & Altitude, $\mathrm{m}$ & $\Delta \mathrm{CN} / \Delta \mathrm{CO}, \mathrm{cm}^{-3} \mathrm{ppb}^{-1}$ & $r^{2}$ & $N$ \\
\hline \multicolumn{7}{|l|}{ Fire Plumes } \\
\hline A10-A & 25 Nov 08 & $13: 15$ & 1450 & $27.3 \pm 0.4$ & 0.90 & 404 \\
\hline A10-C & 25 Nov 08 & $13: 37$ & 1000 & $55.8 \pm 2.0$ & 0.87 & 111 \\
\hline A10-D & 25 Nov 08 & $15: 14$ & 950 & $23.9 \pm 1.2$ & 0.79 & 110 \\
\hline A11-A & 26 Nov 08 & $11: 53$ & 1900 & $36.3 \pm 2.1$ & 0.84 & 57 \\
\hline A11-B & 26 Nov 08 & $13: 02$ & 1800 & $51.8 \pm 3.0$ & 0.78 & 87 \\
\hline A11-C & 26 Nov 08 & $13: 57$ & 450 & $71.9 \pm 2.7$ & 0.93 & 56 \\
\hline A11-D & 26 Nov 08 & $14: 01$ & 1000 & $55.5 \pm 1.6$ & 0.95 & 58 \\
\hline A11-E & 26 Nov 08 & $15: 05$ & 530 & $96.4 \pm 5.1$ & 0.87 & 54 \\
\hline B05-A & 19 May 09 & $18: 21$ & 1100 & $58.7 \pm 2.9$ & 0.95 & 22 \\
\hline Average & & & & $53.1 \pm 22.6$ & & \\
\hline \multicolumn{7}{|l|}{ Regional Haze } \\
\hline A10-B & 25 Nov 08 & $13: 20-14: 40$ & & $17.2 \pm 0.3$ & 0.73 & 1135 \\
\hline \multicolumn{7}{|l|}{ Urban Plumes } \\
\hline B07-A (Santarem) & 21 May 09 & $17: 37$ & 250 & $175 \pm 9$ & 0.95 & 28 \\
\hline B08-A (Belem) & 22 May 09 & $12: 32$ & 470 & $305 \pm 30$ & 0.83 & 24 \\
\hline B08-B (Belem) & 22 May 09 & $16: 17$ & 270 & $380 \pm 28$ & 0.70 & 80 \\
\hline B12-A (Manaus) & 26 May 09 & $21: 05$ & 380 & $441 \pm 23$ & 0.91 & 39 \\
\hline Average & & & & $325 \pm 115$ & & \\
\hline
\end{tabular}
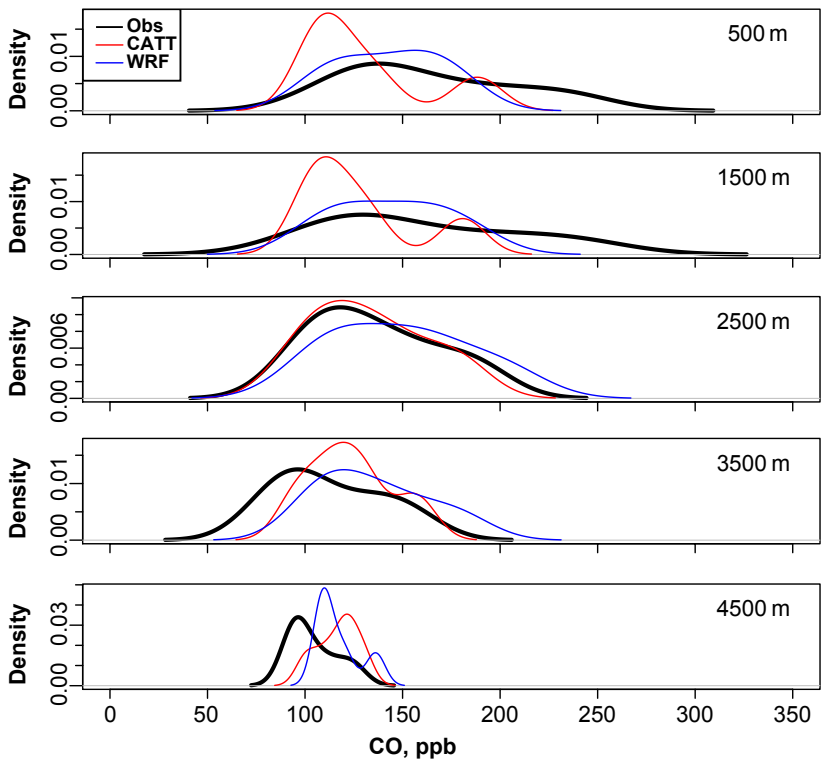

Fig. 13. Probability density distributions for $\mathrm{CO}$ concentrations in BARCA-A, by altitude (excluding Manaus vicinity), for the CATTBRAMS and WRF-Chem models, compared to observations.

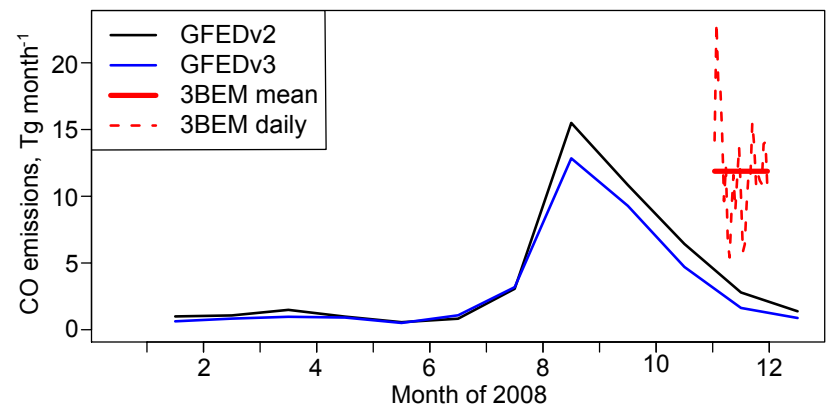

Fig. 14. Biomass burning $\mathrm{CO}$ emissions integrated over the STILT model domain covering most of South America (see bottom of Fig. 2) from different emission models in $\mathrm{Tg}_{\text {month }}{ }^{-1}$ during 2008. GFEDv2: black line, GFEDv3: blue line, 3BEM: red line, 3BEM daily fluxes: red dashed line.

in simulated $\mathrm{CO}$ along the flight path when taking plume rise into account is related to the specific distribution of biomass burning areas upstream of the observations. Taking this impact of plume rise and the associated uncertainty into account, the constraint of BARCA-A observations on the magnitude of the biomass burning emissions is weakened. Overall, accounting for transport model differences and plume rise uncertainty, we estimate the 3BEM emissions to be accurate within about $20 \%$. It is possible that treatments of plume rise may affect conclusions about the cause of discrepancies in 
the vertical distribution, although the manipulations we carried out did not show improved vertical profiles overall.

The fact that the regional models show much better agreement with the observations than the global GEMS reanalysis might indicate a low bias in the underlying fire emissions of $\mathrm{CO}$, which are based on the global fire emission database GFEDv2 (Randerson et al., 2006). A comparison of GFEDv2 monthly emissions for South America (STILT model domain, $35^{\circ} \mathrm{S} 85^{\circ} \mathrm{W}$ to $15^{\circ} \mathrm{N} 30^{\circ} \mathrm{W}$ ) during 2008 with those from 3BEM (Fig. 14) indicates a strong drop in $\mathrm{CO}$ emissions from August (15.5 $\mathrm{Tg}_{\mathrm{month}}{ }^{-1}$ ) to November $\left(2.8 \mathrm{Tg} \mathrm{month}^{-1}\right)$. The monthly $\mathrm{CO}$ fluxes from 3BEM for November 2008 are $11.9 \mathrm{Tg} \mathrm{month}^{-1}$, more than four times higher. Given the consistency of the 3BEM emissions with the BARCA-A observations, we conclude that GFEDv2 biomass burning emissions for $\mathrm{CO}$ have a low bias on the order of a factor of four. This is also consistent with an earlier comparison, which showed a factor three lower emissions in GFEDv2 relative to 3BEM during September and October 2002 (Longo et al., 2010). The recent update of the GFED database to GFEDv3 (van der Werf et al., 2010) shows even lower $\mathrm{CO}$ emissions of $1.6 \mathrm{Tg}_{\mathrm{month}}{ }^{-1}$ during November 2008, corresponding to a low bias of roughly a factor of seven during the BARCA-A period. The strong day-to-day variations in emissions (dashed red line in Fig. 14) clearly indicate the importance of using daily fluxes when comparing to campaign data such as those collected during BARCA.

\section{Summary and conclusions}

We conducted two aircraft campaigns over the Amazon Basin, one during the late dry season (November-December 2008, BARCA-A), the other during the late wet season (May-June 2009, BARCA-B). The primary goal of these campaigns was to address the question of basin scale sources and sinks of $\mathrm{CO}_{2}$ and other atmospheric carbon species. In this paper, we present the results of measurements of $\mathrm{CO}$ mixing ratios and aerosol particle number concentrations $(\mathrm{CN})$ made during BARCA, and analyze them as tracers of biogenic and combustion emissions and atmospheric transport processes.

The seasonal shift in the position of the ITCZ was reflected in the airmass origins that prevailed during the two campaigns. During BARCA-A, trajectory analysis and measurements of the tracer, $\mathrm{SF}_{6}$, indicated that airmasses over the Amazon Basin originated predominantly from the Southern Hemisphere. During BARCA-B low-level airmasses arrived mostly from the Northern Hemisphere, while midtropospheric airmasses came from both hemispheres. These observations highlight the fact, which was already observed during the ABLE campaigns some 20 years earlier, that longrange transport, convergence into the Central Basin, and the location of the ITCZ are important controls on the compo- sition of the Amazonian atmosphere and consequently on biosphere-atmosphere interactions in this region.

Biomass burning, especially along the eastern and southern margins of the Basin, dominated the variability of $\mathrm{CO}$ and $\mathrm{CN}$ concentrations in the study region during BARCAA. The $\mathrm{CO}$ mixing ratios were enhanced up to $300 \mathrm{ppb}$ over background levels of ca. $100 \mathrm{ppb}$, and $\mathrm{CN}$ concentrations approached $10000 \mathrm{~cm}^{-3}$. The highest values were observed in the southern part of the Basin, where both advection of smoke from widespread and intense fires in the region near the coast and local burning in Mato Grosso and Pará States contributed to air pollution. Aerosols and gaseous smoke components were most abundant in the PBL up to ca. $2 \mathrm{~km}$, with peak concentrations in plumes and smoke layers that occasionally reached almost $3 \mathrm{~km}$ altitude.

In fresh smoke plumes, we observed average $\mathrm{CO} / \mathrm{CO}_{2}$ emission ratios of $(79 \pm 14) \times 10^{-3}$. Including reasonable estimates of the contribution of residual smoldering combustion (RSC), especially during nighttime following deforestation fires we propose a value of about $100 \times 10^{-3}$ as a best estimate for the ratio of $\mathrm{CO}$ to $\mathrm{CO}_{2}$ that has been contributed by fires to the regional enhancements of both gases. Given the importance of accurate $\mathrm{CO} / \mathrm{CO}_{2}$ emission ratios for the evaluation of $\mathrm{CO}_{2}$ fluxes from biomass burning and biospheric exchange, future measurement campaigns should focus on better characterization of the role of residual smoldering emissions on the overall trace gas budget from forest burning. The $\triangle \mathrm{CN} / \triangle \mathrm{CO}$ ratios in the smoke polluted regions during BARCA-A showed values around $20 \mathrm{~cm}^{-3} \mathrm{ppb}^{-1}$, typical for aged biomass burning emissions. Fresh plumes yielded an overall average emission ratio of $53 \pm 22 \mathrm{~cm}^{-3} \mathrm{ppb}^{-1}$, within the range previously observed in Amazonia.

In strong contrast to BARCA-A, there was little evidence for a significant presence of biomass smoke pollution in the late wet season during BARCA-B. We found low $\mathrm{CN}$ concentrations $\left(300-500 \mathrm{~cm}^{-3}\right)$ basinwide, confirming other local CN measurements in clean parts of Amazonia during previous campaigns (Roberts et al., 2001; Guyon et al., 2003; Andreae et al., 2004; Rissler et al., 2004; Andreae, 2009). The CO mixing ratios in the PBL were elevated by only $\sim 10 \mathrm{ppb}$ above the values in air entering the Basin from the Atlantic, and no CO enhancement was evident in the FT. The small enhancement of $\mathrm{CO}$ in the PBL relative to the FT (ca. $10 \mathrm{ppb}$ ) agreed with a similar gradient observed 22 years earlier during ABLE-2B, supporting the view that $\mathrm{CO}$ production from diffuse biogenic sources (photochemical degradation of biogenic volatile organic compounds or direct biological emission) is significant, leading to the observed $\sim 10 \mathrm{ppb}$ excess $\mathrm{CO}$ in the PBL. The relatively small contribution of biogenic sources to the Amazonian $\mathrm{CO}$ budget is in strong contrast to the situation for methane, where emissions from wetlands play a dominant role (Beck et al., 2012). Notable influence of $\mathrm{CO}$ from the Northern Hemisphere and from Africa during BARCA-B, although not as prevalent as in ABLE-2B, remind us that insoluble gas phase pollutants are 
imported into Amazonia year round, even when aerosol levels are very low due to efficient scavenging.

We examined the performance of several emission inventories and chemistry-transport models in predicting $\mathrm{CO}$ distributions during BARCA-A, and found rough agreement in spatial distribution. The models confirmed the important role of biomass burning emissions, which provided some $30 \%$ of the absolute amounts and were responsible for ca. $95 \%$ of the variability of $\mathrm{CO}$ during BARCA-A. However, the models also showed some systematic quantitative differences compared to observed $\mathrm{CO}$ concentrations. The global GEMS reanalysis yielded a significant underestimate of the biomass burning contribution. Comparison of the 3BEM biomass burning emissions used for the high-resolution simulations, which yielded results consistent with observations, against those from GFED indicated a large underestimation for GFEDv2 and GFEDv3 emissions of a factor four and seven, respectively, during the November 2008 period. Notable mismatches between models and observations appeared to be related to problems with the accuracy of the global background fields, to inadequate simulation of the rate of vertical transport during transit from source regions into the Central Basin (vertical redistribution was too fast in the models), as well as to representation of smoke injection height, the choice of model resolution, and the reliability and temporal resolution of the emissions data base. These are important issues to assess in detailed analysis of this suite of high-resolution chemistry-transport models.

Acknowledgements. We are grateful to the entire LBA/BARCA team for helping to execute this challenging field mission: $\mathrm{M}$. Longo, V. Y. Chow, B. C. Daube, and E. W. Gottlieb from Harvard University; O. Kolle, J. Steinbach, and H. Chen from MPI-BGC Jena; N. Jürgens, M. Welling from MPIC Mainz; M. A. F. da Silva Dias, F. Moraes and A. Camargo Ribeiro from USP; S. Freitas from INPE; and the INPE flight crew, P. Celso and D. Gramacho. LBA/BARCA was a component of the LBA project, coordinated by INPA - Instituto Nacional de Pesquisas da Amazônia. We would like to thank A. Jordan and M. Rothe from the GasLab at MPI BGC for trace gas analysis of flask samples. We gratefully acknowledge the GEMS project (http://gems.ecmwf.int) for providing the CO reanalysis data. We further thank E. J. Dlugokencky and P. C. Novelli for permission to use unpublished $\mathrm{SF}_{6}$ and $\mathrm{CO}$ data from the NOAA ESRL stations, and J. W. Kaiser and M. Razinger for the FRP plots used in Fig. 2. The flight program and the work at Harvard were supported by NASA grants NASA NNX09AU40G, NNG06GG69A, and NNX08AP68A to Harvard University. The program in Brazil was supported by FAPESP thematic project AEROCLIMA 2008/58100-2 and CNPq Project 477575/2008-0, and MCT and INPE. The German contribution to BARCA was supported by the Max Planck Society.

The service charges for this open access publication have been covered by the Max Planck Society.

Edited by: A. Arneth

\section{References}

Akagi, S. K., Yokelson, R. J., Wiedinmyer, C., Alvarado, M. J., Reid, J. S., Karl, T., Crounse, J. D., and Wennberg, P. O.: Emission factors for open and domestic biomass burning for use in atmospheric models, Atmos. Chem. Phys., 11, 4039-4072, doi:10.5194/acp-11-4039-2011, 2011.

Alonso, M. F., Longo, K., Freitas, S., Fonseca, R., Marécal, V., Pirre, M., and Klenner, L.: An urban emissions inventory for South America and its application in numerical modeling of atmospheric chemical composition at local and regional scales, Atmos. Environ., 44, 5072-5083, 2010.

Alvala, P. C. and Kirchhoff, V. W. J. H.: Observations of atmospheric methane and carbon monoxide in Brazil: SCAR-B mission, J. Geophys. Res., 103, 32101-32105, 1998.

Andreae, M. O.: Correlation between cloud condensation nuclei concentration and aerosol optical thickness in remote and polluted regions, Atmos. Chem. Phys., 9, 543-556, doi:10.5194/acp-9-543-2009, 2009.

Andreae, M. O. and Merlet, P.: Emission of trace gases and aerosols from biomass burning, Global Biogeochem. Cy., 15, 955-966, 2001.

Andreae, M. O. and Rosenfeld, D.: Aerosol-cloud-precipitation interactions. Part 1. The nature and sources of cloud-active aerosols, Earth Sci. Rev., 89, 13-41, 2008.

Andreae, M. O., Browell, E. V., Garstang, M., Gregory, G. L., Harriss, R. C., Hill, G. F., Jacob, D. J., Pereira, M. C., Sachse, G. W., Setzer, A. W., Dias, P. L. S., Talbot, R. W., Torres, A. L., and Wofsy, S. C.: Biomass-burning emissions and associated haze layers over Amazonia, J. Geophys. Res., 93, 1509-1527, 1988.

Andreae, M. O., Berresheim, H., Bingemer, H., Jacob, D. J., Lewis, B. L., Li, S.-M., and Talbot, R. W.: The atmospheric sulfur cycle over the Amazon Basin, 2. Wet Season, J. Geophys. Res., 95, 16813-16824, 1990.

Andreae, M. O., Anderson, B. E., Blake, D. R., Bradshaw, J. D., Collins, J. E., Gregory, G. L., Sachse, G. W., and Shipham, M. C.: Influence of plumes from biomass burning on atmospheric chemistry over the equatorial Atlantic during CITE-3, J. Geophys. Res., 99, 12793-12808, 1994.

Andreae, M. O., Artaxo, P., Brandão, C., Carswell, F. E., Ciccioli, P., da Costa, A. L., Culf, A. D., Esteves, J. L., Gash, J. H. C., Grace, J., Kabat, P., Lelieveld, J., Malhi, Y., Manzi, A. O., Meixner, F. X., Nobre, A. D., Nobre, C., Ruivo, M. d. L. P., Silva-Dias, M. A., Stefani, P., Valentini, R., von Jouanne, J., and Waterloo, M. J.: Biogeochemical cycling of carbon, water, energy, trace gases and aerosols in Amazonia: The LBA-EUSTACH experiments, J. Geophys. Res., 107, 8066, doi:10.1029/2001JD000524, 2002.

Andreae, M. O., Rosenfeld, D., Artaxo, P., Costa, A. A., Frank, G. P., Longo, K. M., and Silva-Dias, M. A. F.: Smoking rain clouds over the Amazon, Science, 303, 1337-1342, 2004.

Artaxo, P., Storms, H., Bruynseels, F., Grieken, R. V., and Maenhaut, W.: Composition and sources of aerosols from the Amazon basin, J. Geophys. Res., 93, 1605-1615, 1988.

Artaxo, P., Maenhaut, W., Storms, H., and Grieken, R. V.: Aerosol characteristics and sources for the Amazon Basin during the wet season, J. Geophys. Res., 95, 16971-16986, 1990.

Baars, H., Ansmann, A., Althausen, D., Engelmann, R., Artaxo, P., Pauliquevis, T., and Souza, R.: Further evidence for significant smoke transport from Africa to Amazonia, Geophys. Res. Lett., 38, L20802, doi:10.1029/2011GL049200, 2011. 
Babbitt, R. E., Ward, D. E., Susott, R. A., Artaxo, P., and Kauffman, J. B.: A comparison of concurrent airborne and ground-based emissions generated from biomass burning in the Amazon basin, in: SCAR-B Proceedings, edited by: Kirchhoff, V. W. J. H., 2326, Transtec Editorial, Sao Jose dos Campos, Brazil, 1996.

Bauer, K., Seiler, W., and Giehl, H.: CO production by higher plants, Zeitschrift für Pflanzenphysiologie, 94, 219-230, 1979.

Beck, V., Koch, T., Kretschmer, R., Marshall, J., Ahmadov, R., Gerbig, C., Pillai, D., and Heimann, M.: The WRF Greenhouse Gas Model (WRF-GHG), Technical Report No. 25. Max Planck Institute for Biogeochemistry, Jena, Germany, 2011.

Beck, V., Chen, H., Gerbig, C., Bergamaschi, P., Bruhwiler, L., Houweling, S., Röckmann, T., Kolle, O., Steinbach, J., Koch, T., Sapart, C. J., van der Veen, C., Frankenberg, C., Andreae, M. O., Artaxo, P., Longo, K. M., and Wofsy, S. C.: Methane airborne measurements and comparison to global models during BARCA, J. Geophys. Res., in press, 2012.

Ben-Ami, Y., Koren, I., and Altaratz, O.: Patterns of North African dust transport over the Atlantic: winter vs. summer, based on CALIPSO first year data, Atmos. Chem. Phys., 9, 7867-7875, doi:10.5194/acp-9-7867-2009, 2009.

Ben-Ami, Y., Koren, I., Rudich, Y., Artaxo, P., Martin, S. T., and Andreae, M. O.: Transport of North African dust from the Bodélé depression to the Amazon Basin: a case study, Atmos. Chem. Phys., 10, 7533-7544, doi:10.5194/acp-10-7533-2010, 2010.

Browell, E. V., Fenn, M. A., Butler, C. F., Grant, W. B., Clayton, M. E., Fishman, J., Bachmeier, A. S., Anderson, B. E., Gregory, G. L., Fuelberg, H. E., Bradshaw, J. D., Sandholm, S. T., Blake, D. R., Heikes, B. G., Sachse, G. W., Singh, H. B., and Talbot, R. W.: Ozone and aerosol distributions and air mass characteristics over the South Atlantic basin during the burning season, J. Geophys. Res., 101, 24043-24068, 1996.

Cantrell, C. A.: Technical Note: Review of methods for linear leastsquares fitting of data and application to atmospheric chemistry problems, Atmos. Chem. Phys., 8, 5477-5487, doi:10.5194/acp8-5477-2008, 2008.

Carswell, F. E., Costa, A. L., Palheta, M., Malhi, Y., Meir, P., Costa, J. d. P. R., Ruivo, M. d. L., Leal, L. d. S. M., Costa, J. M. N., Clement, R. J., and Grace, J.: Seasonality in $\mathrm{CO}_{2}$ and $\mathrm{H}_{2} \mathrm{O}$ flux at an eastern Amazonian rain forest: J. Geophys. Res., 107, LBA 43-1-LBA 43-15, doi:10.1029/2000JD000284, 2002.

Chambers, J. Q., Higuchi, N., Teixeira, L. M., dos Santos, J., Laurance, S. G., and Trumbore, S. E.: Response of tree biomass and wood litter to disturbance in a Central Amazon forest, Oecologia, 141, 596-611, doi:10.1007/s00442-004-1676-2, 2004.

Chen, Q., Farmer, D. K., Schneider, J., Zorn, S. R., Heald, C. L., Karl, T., Guenther, A., Allan, J. D., Robinson, N., Coe, H., Kimmel, J. R., Pauliquevis, T., Borrmann, S., Pöschl, U., Andreae, M. O., Artaxo, P., Jimenez, J. L., and Martin, S. T.: Mass spectral characterization of submicron biogenic organic particles in the Amazon Basin, Geophys. Res. Lett., L20806, doi:10.1029/2009GL03988, 2009.

Chou, W. W., Wofsy, S. C., Harriss, R. C., Lin, J. C., Gerbig, C., and Sachse, G. W.: Net fluxes of $\mathrm{CO}_{2}$ in Amazonia derived from aircraft observations, J. Geophys. Res., 107, 4614, doi:10.1029/2001JD001295, 2002.

Conrad, R. and Seiler, W.: Characteristics of a biological carbon monoxide formation from soil organic matter, humic acids and phenolic compounds, Environ. Sci. Technol., 19, 1165-1176,
1985.

Daube, B. C., Boering, K. A., Andrews, A. E., and Wofsy, S. C., A high-precision fast-response airborne $\mathrm{CO}_{2}$ analyzer for in situ sampling from the surface to the middle stratosphere, J. Atmos. Ocean. Technol., 19, 1532-1543, doi:10.1175/15200426(2002)019<1532:ahpfra >2.0.CO;2, 2002.

Draxler, R. R. and Rolph, G. D.: HYSPLIT (HYbrid Single-Particle Lagrangian Integrated Trajectory) Model access via NOAA ARL READY Website, http://www.arl.noaa.gov/ready/hysplit4.html, NOAA Air Resources Laboratory, Silver Spring, MD, USA, 2003.

Duncan, B. N. and Logan, J. A.: Model analysis of the factors regulating the trends and variability of carbon monoxide between 1988 and 1997, Atmos. Chem. Phys., 8, 7389-7403, doi:10.5194/acp-8-7389-2008, 2008.

Duncan, B. N., Logan, J. A., Bey, I., Megretskaia, I. A., Yantosca, R. M., Novelli, P. C., Jones, N. B., and Rinsland, C. P.: Global budget of CO, 1988-1997: Source estimates and validation with a global model, J. Geophys. Res., 112, D22301, doi:10.1029/2007jd008459, 2007.

Edwards, D. P., Emmons, L. K., Gille, J. C., Chu, A., Attie, J. L., Giglio, L., Wood, S. W., Haywood, J., Deeter, M. N., Massie, S. T., Ziskin, D. C., and Drummond, J. R.: Satellite-observed pollution from Southern Hemisphere biomass burning, J. Geophys. Res., 111, D14312, doi:10.1029/2005jd006655, 2006.

Fan, S.-M., Wofsy, S. C., Bakwin, P. S., Jacob, D. J., and Fitzjarrald, D. R.: Atmosphere-biosphere exchange of $\mathrm{CO}_{2}$ and $\mathrm{O}_{3}$ in the central Amazon forest, J. Geophys. Res., 95, 16851-16864, 1990.

Ferek, R. J., Reid, J. S., Hobbs, P. V., Blake, D. R., and Liousse, C.: Emission factors of hydrocarbons, halocarbons, trace gases and particles from biomass burning in Brazil, J. Geophys. Res., 103, 32107-32118, 1998.

Formenti, P., Andreae, M. O., Lange, L., Roberts, G., Cafmeyer, J., Rajta, I., Maenhaut, W., Holben, B. N., Artaxo, P., and Lelieveld, J.: Saharan dust in Brazil and Suriname during the Large-Scale Biosphere-Atmosphere Experiment in Amazonia (LBA)- Cooperative LBA Regional Experiment (CLAIRE) in March 1998, J. Geophys. Res., 106, 14919-14934, 2001.

Freitas, S. R., Longo, K. M., Silva Dias, M. A. F., Chatfield, R., Silva Dias, P., Artaxo, P., Andreae, M. O., Grell, G., Rodrigues, L. F., Fazenda, A., and Panetta, J.: The Coupled Aerosol and Tracer Transport model to the Brazilian developments on the Regional Atmospheric Modeling System (CATT-BRAMS) - Part 1: Model description and evaluation, Atmos. Chem. Phys., 9, 28432861, doi:10.5194/acp-9-2843-2009, 2009.

Freitas, S. R., Longo, K. M., Alonso, M. F., Pirre, M., Marecal, V., Grell, G., Stockler, R., Mello, R. F., and Sánchez Gácita, M.: PREP-CHEM-SRC - 1.0: a preprocessor of trace gas and aerosol emission fields for regional and global atmospheric chemistry models, Geosci. Model Dev., 4, 419-433, doi:10.5194/gmd-4419-2011, 2011.

Gatti, L. V., Miller, J. B., D’Amelio, M. T. S., Martinewski, A., Basso, L. S., Gloor, M. E., Wofsy, S., and Tans, P.: Vertical profiles of $\mathrm{CO}_{2}$ above eastern Amazonia suggest a net carbon flux to the atmosphere and balanced biosphere between 2000 and 2009: Tellus B - Chem. Phys. Meteorol., 62, 581-594, doi:10.1111/j.1600-0889.2010.00484.x, 2010. 
Gerbig, C., Lin, J. C., Wofsy, S. C., Daube, B. C., Andrews, A. E., Stephens, B. B., Bakwin, P. S., and Grainger, C. A.: Toward constraining regional-scale fluxes of $\mathrm{CO}_{2}$ with atmospheric observations over a continent: 1 . Observed spatial variability from airborne platforms, J. Geophys. Res., 108, 4756, doi:10.1029/2002jd003018, 2003a.

Gerbig, C., Lin, J. C., Wofsy, S. C., Daube, B. C., Andrews, A. E., Stephens, B. B., Bakwin, P. S., and Grainger, C. A.: Toward constraining regional-scale fluxes of $\mathrm{CO}_{2}$ with atmospheric observations over a continent: 2 . Analysis of COBRA data using a receptor-oriented framework, J. Geophys. Res., 108, 4757, doi:10.1029/2003jd003770, 2003b.

Gevaerd, R. and Freitas, S. R.: Estimativa operacional da umidade do solo para iniciação de modelos de previsão numérica da atmosfera. Parte I: Descrição da metodologia e validação: Revista Brasileira de Meteorologia, 21, 59-73, 2006.

Gilardoni, S., Vignati, E., Marmer, E., Cavalli, F., Belis, C., Gianelle, V., Loureiro, A., and Artaxo, P.: Sources of carbonaceous aerosol in the Amazon basin, Atmos. Chem. Phys., 11, 27472764, doi:10.5194/acp-11-2747-2011, 2011.

Gloor, M., Fan, S. M., Pacala, S., Sarmiento, J., and Ramonet, M.: A model-based evaluation of inversions of atmospheric transport, using annual mean mixing ratios, as a tool to monitor fluxes of nonreactive trace substances like $\mathrm{CO}_{2}$ on a continental scale, $\mathrm{J}$. Geophys. Res., 104, 14245-14260, 1999.

Grace, J., Lloyd, J., McIntyre, J., Miranda, A., Meir, P., Miranda, H., Moncrieff, J., Massheder, J., Wright, I., and Gash, J.: Fluxes of carbon dioxide and water vapor over an undisturbed tropical forest in south-west Amazonia, Global Change Biol., 1, 1-12, 1995a.

Grace, J., Lloyd, J., McIntyre, J., Miranda, A. C., Meir, P., Miranda, H. S., Nobre, C., Moncrieff, J., Massheder, J., Malhi, Y., Wright, I., and Gash, J.: Carbon dioxide uptake by an undisturbed tropical rain forest in southwest Amazonia, 1992 to 1993, Science, 270, 778-780, 1995b.

Greenberg, J. P., Zimmerman, P. R., Heidt, L., and Pollock, W.: Hydrocarbon and carbon monoxide emissions from biomass burning in Brazil, J. Geophys. Res., 89, 1350-1354, 1984.

Grell, G. A., Peckham, S. E., Schmitz, R., McKeen, S. A., Frost, G., Skamarock, W. C., and Eder, B.: Fully coupled online chemistry within the WRF model, Atmos. Environ., 39, 6957-6975, 2005.

Guyon, P., Graham, B., Beck, J., Boucher, O., Gerasopoulos, E., Mayol-Bracero, O. L., Roberts, G. C., Artaxo, P., and Andreae, M. O.: Physical properties and concentration of aerosol particles over the Amazon tropical forest during background and biomass burning conditions, Atmos. Chem. Phys., 3, 951-967, doi:10.5194/acp-3-951-2003, 2003.

Guyon, P., Frank, G. P., Welling, M., Chand, D., Artaxo, P., Rizzo, L., Nishioka, G., Kolle, O., Fritsch, H., Silva Dias, M. A. F, Gatti, L. V., Cordova, A. M., and Andreae, M. O.: Airborne measurements of trace gas and aerosol particle emissions from biomass burning in Amazonia, Atmos. Chem. Phys., 5, 29893002, doi:10.5194/acp-5-2989-2005, 2005.

Harriss, R. C., Wofsy, S. C., Garstang, M., Browell, E. V., Molion, L. C. B., McNeal, R. J., Hoell, J. M., Bendura, R. J., Beck, S. M., Navarro, R. L., Riley, J. T., and Snell, R. L.: The Amazon Boundary Layer Experiment (ABLE-2A): Dry Season 1985, J. Geophys. Res., 93, 1351-1360, 1988.
Harriss, R. C., Garstang, M., Wofsy, S. C., Beck, S. M., Bendura, R. J., Coelho, J. R. B., Drewry, J. W., Hoell, J. M., Matson, P. A., McNeal, R. J., Molion, L. C. B., Navarro, R. L., Rabine, V., and Snell, R. L.: The Amazon Boundary Layer Experiment: Wet Season 1987, J. Geophys. Res., 95, 16721-16736, 1990a.

Harriss, R. C., Sachse, G. W., Hill, G. F., Wade, L. O., and Gregory, G. L.: Carbon monoxide over the Amazon Basin during the wet season, J. Geophys. Res., 95, 16927-16932, 1990 b.

Hobbs, P. V., Sinha, P., Yokelson, R. J., Christian, T. J., Blake, D. R., Gao, S., Kirchstetter, T. W., Novakov, T., and Pilewskie, P.: Evolution of gases and particles from a savanna fire in South Africa, J. Geophys. Res., 108, 8485, doi:10.1029/2002JD002352, 2003.

Holloway, T., Levy, H., and Kasibhatla, P.: Global distribution of carbon monoxide, J. Geophys. Res., 105, 12123-12147, 2000.

Jacob, D. J. and Wofsy, S. C.: Photochemistry of biogenic emissions over the Amazon forest, J. Geophys. Res., 93, 1477-1486, 1988.

Janhäll, S., Andreae, M. O., and Pöschl, U.: Biomass burning aerosol emissions from vegetation fires: particle number and mass emission factors and size distributions, Atmos. Chem. Phys., 10, 1427-1439, doi:10.5194/acp-10-1427-2010, 2010.

Jiang, J. H., Su, H., Schoeberl, M. R., Massie, S. T., Colarco, P., Platnick, S., and Livesey, N. J.: Clean and polluted clouds: Relationships among pollution, ice clouds, and precipitation in South America, Geophys. Res. Lett., 35, L14804, doi:10.1029/2008GL034631, 2008.

Kaiser, J. W., Heil, A., Andreae, M. O., Benedetti, A., Chubarova, N., Jones, L., Morcrette, J.-J., Razinger, M., Schultz, M. G., Suttie, M., and van der Werf, G. R.: Biomass burning emissions estimated with a global fire assimilation system based on observed fire radiative power, Biogeosciences, 9, 527-554, doi:10.5194/bg-9-527-2012, 2012.

Kaufman, Y. J., Tucker, C. J., and Fung, I.: Remote sensing of biomass burning in the tropics, J. Geophys. Res., 95, 9927-9939, 1990.

Kaufman, Y. J., Tanré, D., and Boucher, O.: A satellite view of aerosols in the climate system, Nature, 419, 215-223, 2002.

Kirchhoff, V., Aires, C. B., and Alvala, P. C.: An experiment to determine atmospheric CO concentrations of tropical South Atlantic air samples, Q. J. Roy. Meterorol. Soc., 129, 1891-1902, doi:10.1256/qj.02.142, 2003.

Kirchhoff, V. W. J. H. and Alvalá, P. C.: Overview of an aircraft expedition into the Brazilian cerrado for the observation of atmospheric trace gases, J. Geophys. Res., 101, 23973-23982, 1996.

Kirchhoff, V. W. J. H. and Marinho, E. V. A.: Surface carbon monoxide measurements in Amazonia, J. Geophys. Res., 95, 16933-16943, 1990.

Kirchhoff, V. W. J. H. and Rasmussen, R. A., Time variations of CO and $\mathrm{O} 3$ concentrations in a region subject to biomass burning, $\mathrm{J}$. Geophys. Res., 95, 7521-7532, 1990.

Koren, I., Kaufman, Y. J., Remer, L. A., and Martins, J. V.: Measurement of the effect of Amazon smoke on inhibition of cloud formation, Science, 303, 1342-1345, 2004.

Kort, E. A., Eluszkiewicz, J., Stephens, B. B., Miller, J. B., Gerbig, C., Nehrkorn, T., Daube, B. C., Kaplan, J. O., Houweling, S., and Wofsy, S. C.: Emissions of $\mathrm{CH}_{4}$ and $\mathrm{N}_{2} \mathrm{O}$ over the United States and Canada based on a receptor-oriented modeling framework and COBRA-NA atmospheric observations, Geophys. Res. Lett., 35, L18808, doi:10.1029/2008g1034031, 2008. 
Kuhn, U., Ganzeveld, L., Thielmann, A., Dindorf, T., Schebeske, G., Welling, M., Sciare, J., Roberts, G., Meixner, F. X., Kesselmeier, J., Lelieveld, J., Kolle, O., Ciccioli, P., Lloyd, J., Trentmann, J., Artaxo, P., and Andreae, M. O.: Impact of Manaus City on the Amazon Green Ocean atmosphere: ozone production, precursor sensitivity and aerosol load, Atmos. Chem. Phys., 10, 9251-9282, doi:10.5194/acp-10-9251-2010, 2010.

Le Canut, P., Andreae, M. O., Harris, G. W., Wienhold, F. G., and Zenker, T.: Airborne studies of emissions from savanna fires in southern Africa, 1, Aerosol emissions measured with a laser optical particle counter, J. Geophys. Res., 101, 23615-23630, 1996.

Levin, I., Naegler, T., Heinz, R., Osusko, D., Cuevas, E., Engel, A., Ilmberger, J., Langenfelds, R. L., Neininger, B., Rohden, C. v., Steele, L. P., Weller, R., Worthy, D. E., and Zimov, S. A.: The global $\mathrm{SF}_{6}$ source inferred from long-term high precision atmospheric measurements and its comparison with emission inventories, Atmos. Chem. Phys., 10, 2655-2662, doi:10.5194/acp-102655-2010, 2010. Bibtex EndNote Reference Manager XML

Lin, J. C., Gerbig, C., Wofsy, S. C., Andrews, A. E., Daube, B. C., Davis, K. J., and Grainger, C. A.: A near-field tool for simulating the upstream influence of atmospheric observations: the Stochastic Time-Inverted Lagrangian Transport (STILT) model, J. Geophys. Res., 108, ACH2-1-17, doi:10.1029/2002jd003161, 2003.

Lin, J. C., Gerbig, C., Wofsy, S. C., Andrews, A. E., Daube, B. C., Grainger, C. A., Stephens, B. B., Bakwin, P. S., and Hollinger, D. Y.: Measuring fluxes of trace gases at regional scales by Lagrangian observations: Application to the $\mathrm{CO}_{2}$ Budget and Rectification Airborne (COBRA) study, J. Geophys. Res., 109, D15304, doi:10.1029/2004JD004754, 2004.

Lin, J. C., Matsui, T., Pielke Sr., R. A.,, and Kummerow, C.: Effects of biomass burning-derived aerosols on precipitation and clouds in the Amazon basin: a satellite-based empirical study, J. Geophys. Res., 111, D19204, doi:10.1029/2005JD006884, 2006.

Lloyd, J., Kolle, O., Fritsch, H., de Freitas, S. R., Silva Dias, M. A. F., Artaxo, P., Nobre, A. D., de Araújo, A. C., Kruijt, B., Sogacheva, L., Fisch, G., Thielmann, A., Kuhn, U., and Andreae, M. O.: An airborne regional carbon balance for Central Amazonia, Biogeosciences, 4, 759-768, doi:10.5194/bg-4-759-2007, 2007.

Logan, J. A., Prather, M. J., Wofsy, S. C., and McElroy, M. B.: Tropospheric chemistry - a global perspective, J. Geophys. Res., 86, 7210-7254, 1981.

Longo, K. M., Freitas, S. R., Andreae, M. O., Yokelson, R., and Artaxo, P.: Biomass burning in Amazonia: Emissions, long range transport of smoke and its regional and remote impacts, in: Amazonia and Global Change, edited by: Keller, M., Bustamante, M., Gash, J., and Dias, P., 207-232, American Geophysical Union, Washington, DC, USA, 2009.

Longo, K. M., Freitas, S. R., Andreae, M. O., Setzer, A., Prins, E., and Artaxo, P.: The Coupled Aerosol and Tracer Transport model to the Brazilian developments on the Regional Atmospheric Modeling System (CATT-BRAMS) - Part 2: Model sensitivity to the biomass burning inventories, Atmos. Chem. Phys., 10, 5785-5795, doi:10.5194/acp-10-5785-2010, 2010.

Macatangay, R., Warneke, T., Gerbig, C., Körner, S., Ahmadov, R., Heimann, M., and Notholt, J.: A framework for comparing remotely sensed and in-situ $\mathrm{CO}_{2}$ concentrations, Atmos. Chem. Phys., 8, 2555-2568, doi:10.5194/acp-8-2555-2008, 2008.
Martin, S. T., Andreae, M. O., Artaxo, P., Baumgardner, D., Chen, Q., Goldstein, A. H., Guenther, A., Heald, C. L., MayolBracero, O. L., McMurry, P. H., Pauliquevis, T., Pöschl, U., Prather, K. A., Roberts, G. C., Saleska, S. R., Dias, M. A. S., Spracklen, D., Swietlicki, E., and Trebs, I.: Sources and properties of Amazonian aerosol particles, Rev. Geophys., 48, RG2002, doi:10.1029/2008RG000280, 2010.

Martins, J. A., Dias, M., and Goncalves, F. L. T.: Impact of biomass burning aerosols on precipitation in the Amazon: A modeling case study, J. Geophys. Res., 114, D02207, doi:10.1029/2007jd009587, 2009.

Matross, D. M., Andrews, A., Pathmathevan, M., Gerbig, C., Lin, J. C., Wofsy, S. C., Daube, B. C., Gottlieb, E. W., Chow, V. Y., Lee, J. T., Zhao, C. L., Bakwin, P. S., Munger, J. W., and Hollinger, D. Y.: Estimating regional carbon exchange in New England and Quebec by combining atmospheric, ground-based and satellite data, Tellus B - Chem. Phys. Meteorol., 58, 344358, doi:10.1111/j.1600-0889.2006.00206.x, 2006.

Miller, S. M., Matross, D. M., Andrews, A. E., Millet, D. B., Longo, M., Gottlieb, E. W., Hirsch, A. I., Gerbig, C., Lin, J. C., Daube, B. C., Hudman, R. C., Dias, P. L. S., Chow, V. Y., and Wofsy, S. C.: Sources of carbon monoxide and formaldehyde in North America determined from high-resolution atmospheric data, Atmos. Chem. Phys., 8, 7673-7696, doi:10.5194/acp-8-7673-2008, 2008.

Nehrkorn, T., Eluszkiewicz, J., Wofsy, S. C., Lin, J. C., Gerbig, C., Longo, M., and Freitas, S.: Coupled weather research and forecasting-stochastic time-inverted lagrangian transport (WRF-STILT) model, Meteorol. Atmos. Phys., 107, 51-64, doi:10.1007/s00703-010-0068-x, 2010.

Nicks, D. K., Holloway, J. S., Ryerson, T. B., Dissly, R. W., Parrish, D. D., Frost, G. J., Trainer, M., Donnelly, S. G., Schauffler, S., Atlas, E. L., Hubler, G., Sueper, D. T., and Fehsenfeld, F. C.: Fossil-fueled power plants as a source of atmospheric carbon monoxide, J. Environ. Monit., 5, 35-39, 2003.

Novelli, P. C., Masarie, K. A., Lang, P. M., Hall, B. D., Myers, R. C., and Elkins, J. W.: Reanalysis of tropospheric CO trends: Effects of the 1997-1998 wildfires, J. Geophys. Res., 108, 4464, doi:10.1029/2002JD003031, 2003.

Oliveira, P. H. F., Artaxo, P., Pires, C., De Lucca, S., Procopio, A., Holben, B., Schafer, J., Cardoso, L. F., Wofsy, S. C., and Rocha, H. R.: The effects of biomass burning aerosols and clouds on the $\mathrm{CO}_{2}$ flux in Amazonia, Tellus, 59B, 338-349, doi:10.1111/j.1600-0889.2007.00270.x, 2007.

Peuch, V.-H., Amodei, M., Barthet, T., Cathala, M.-L., Josse, B., Michou, M., and Simon, P.: MOCAGE, MOdèle de Chimie Atmosphérique à Grande Echelle, Paper presented at the MétéoFrance workshop on atmospheric modelling, France, 33-36, 1999.

Pillai, D., Gerbig, C., Ahmadov, R., Rödenbeck, C., Kretschmer, R., Koch, T., Thompson, R., Neininger, B., and Lavrié, J. V.: High-resolution simulations of atmospheric $\mathrm{CO}_{2}$ over complex terrain - representing the Ochsenkopf mountain tall tower, Atmos. Chem. Phys., 11, 7445-7464, doi:10.5194/acp-11-74452011, 2011.

Pöschl, U., Martin, S. T., Sinha, B., Chen, Q., Gunthe, S. S., Huffman, J. A., Borrmann, S., Farmer, D. K., Garland, R. M., Helas, G., Jimenez, J. L., King, S. M., Manzi, A., Mikhailov, E., Pauliquevis, T., Petters, M. D., Prenni, A. J., Roldin, P., Rose, D., 
Schneider, J., Su, H., Zorn, S. R., Artaxo, P., and Andreae, M. O.: Rainforest aerosols as biogenic nuclei of clouds and precipitation in the Amazon, Science, 329, 1513-1516, 2010.

Potosnak, M. J., Wofsy, S. C., Denning, A. S., Conway, T. J., Munger, J. W., and Barnes, D. H.: Influence of biotic exchange and combustion sources on atmospheric $\mathrm{CO}_{2}$ concentrations in New England from observations at a forest flux tower, J. Geophys. Res., 104, 9561-9569, 1999.

Pougatchev, N. S., Sachse, G. W., Fuelberg, H. E., Rinsland, C. P., Chatfield, R. B., Connors, V. S., Jones, N. B., Notholt, J., Novelli, P. C., and Reichle, H. G.: Pacific Exploratory MissionTropics carbon monoxide measurements in historical context, J. Geophys. Res., 104, 26195-26207, 1999.

Prasad, V. K., Gupta, P. K., Sharma, C., Sarkar, A. K., Kant, Y., Badarinath, K. V. S., Rajagopal, T., and Mitra, A. P.: $\mathrm{NO}_{\mathrm{x}}$ emissions from biomass burning of shifting cultivation areas from tropical deciduous forests of India - estimates from groundbased measurements, Atmos. Environ., 34, 3271-3280, 2000.

Randerson, J. T., Werf, G. R. v. d., Giglio, L., Collatz, G. J., and Kasibhatla, P. S.: Global Fire Emissions Database, Version 2 (GFEDv2): Oak Ridge National Laboratory Distributed Active Archive Center, Oak Ridge, Tennessee, USA, doi:10.3334/ORNLDAAC/834, 2006.

Reichle, H. G., Connors, V. S., Holland, J. A., Hypes, W. D., Wallio, H. A., Casas, J. C., Gormsen, B. B., Saylor, M. S., and Hasketh, W. D.: Middle and upper tropospheric carbon monoxide mixing ratios as measured by a satellite borne remote sensor during November 1981, J. Geophys. Res., 91, 10865-10888, 1986.

Reichle, H. G., Connors, V. S., Holland, J. A., Sherrill, R. T., Wallio, H. A., Casas, J. C., Condon, E. P., Gormsen, B. B., and Seiler, W.: The distribution of middle tropospheric carbon monoxide during early October 1984, J. Geophys. Res., 95, 9845-9856, 1990.

Reichle, H. G., Anderson, B. E., Connors, V. S., Denkins, T. C., Forbes, D. A., Gormsen, B. B., Langenfelds, R. L., Neil, D. O., Nolf, S. R., Novelli, P. C., Pougatchev, N. S., Roell, M. M., and Steele, L. P.: Space shuttle based global CO measurements during April and October 1994, MAPS instrument, data reduction, and data validation, J. Geophys. Res., 104, 21443-21454, 1999.

Rissler, J., Swietlicki, E., Zhou, J., Roberts, G., Andreae, M. O., Gatti, L. V., and Artaxo, P.: Physical properties of the submicrometer aerosol over the Amazon rain forest during the wetto-dry season transition - comparison of modeled and measured CCN concentrations, Atmos. Chem. Phys., 4, 2119-2143, doi:10.5194/acp-4-2119-2004, 2004.

Roberts, G. C., Andreae, M. O., Zhou, J., and Artaxo, P.: Cloud condensation nuclei in the Amazon Basin: "Marine" conditions over a continent?, Geophys. Res. Lett., 28, 2807-2810, 2001.

Rosenfeld, D.: TRMM observed first direct evidence of smoke from forest fires inhibiting rainfall, Geophys. Res. Lett., 26, 31053108, 1999.

Sachse, G. W., Harriss, R. C., Fishman, J., Hill, G. F., and Cahoon, D. R.: Carbon monoxide over the Amazon Basin during the 1985 dry season, J. Geophys. Res., 93, 1422-1430, 1988.

Saleska, S. R., Miller, S. D., Matross, D. M., Goulden, M. L., Wofsy, S. C., da Rocha, H. R., de Camargo, P. B., Crill, P., Daube, B. C., de Freitas, H. C., Hutyra, L., Keller, M., Kirchhoff, V., Menton, M., Munger, J. W., Pyle, E. H., Rice, A. H., and Silva, H.: Carbon in Amazon forests: Unexpected seasonal fluxes and disturbanceinduced losses, Science, 302, 1554-1557, 2003.
Schade, G. W. and Crutzen, P. J.: CO emissions from degrading plant matter (II) - Estimate of a global source strength, Tellus, 51B, 909-918, doi:10.1034/j.1600-0889.1999.t01-400004.x, 1999.

Schade, G. W., Hofmann, R.-M., and Crutzen, P. J.: CO emissions from degrading plant matter (I) - Measurements, Tellus, 51B, 889-908, doi:10.1034/j.1600-0889.1999.t01-4-00003.x, 1999.

Schafer, J. S., Holben, B. N., Eck, T. F., Yamasoe, M. A., and Artaxo, P.: Atmospheric effects on insolation in the Brazilian Amazon: Observed modification of solar radiation by clouds and smoke and derived single scattering albedo of fire aerosols, J. Geophys. Res., 107, 8074, doi:10.1029/2001JD000428, 2002.

Schimel, D. S., House, J. I., Hibbard, K. A., Bousquet, P., Ciais, P., Peylin, P., Braswell, B. H., Apps, M. J., Baker, D., Bondeau, A., Canadell, J., Churkina, G., Cramer, W., Denning, A. S., Field, C. B., Friedlingstein, P., Goodale, C., Heimann, M., Houghton, R. A., Melillo, J. M., Moore, B., Murdiyarso, D., Noble, I., Pacala, S. W., Prentice, I. C., Raupach, M. R., Rayner, P. J., Scholes, R. J., Steffen, W. L., and Wirth, C.: Recent patterns and mechanisms of carbon exchange by terrestrial ecosystems, Nature, 414, 169$172,2001$.

Seiler, W., Giehl, H., and Bunse, G.: Influence of plants on atmospheric carbon monoxide and dinitrogen oxide, Pure Appl. Geophys., 116, 439-451, 1978.

Soares Neto, T. G., Carvalho Jr., J. A.,, Veras, C. A. G., Alvarado, E. C., Gielow, R., Lincoln, E. N., Christian, T. J., Yokelson, R. J., and Santos, J. C.: Biomass consumption and $\mathrm{CO}_{2} \mathrm{CO}$ and main hydrocarbon gas emissions in an Amazonian forest clearing fire, Atmos. Environ., 43, 438-446, doi:10.1016/j.atmosenv.2008.07.063, 2009.

Stockwell, W. R., Kirchner, F., Kuhn, M., and Seefeld, S.: A new mechanism for regional atmospheric chemistry modeling: J. Geophys. Res., 102, 25847-25879, doi:10.1029/97jd00849, 1997.

Swap, R., Garstang, M., Greco, S., Talbot, R., and Kållberg, P.: Saharan dust in the Amazon Basin, Tellus, 44B, 133-149, 1992.

Talbot, R. W., Andreae, M. O., Andreae, T. W., and Harriss, R. C.: Regional aerosol chemistry of the Amazon Basin during the dry season, J. Geophys. Res., 93, 1499-1508, 1988.

Talbot, R. W., Andreae, M. O., Berresheim, H., Artaxo, P., Garstang, M., Harriss, R. C., Beecher, K. M., and Li, S. M.: Aerosol chemistry during the wet season in Central Amazonia: The influence of long-range transport, J. Geophys. Res., 95, 16955-16969, 1990.

Tarr, M. A., Miller, W. L., and Zepp, R. G., Direct carbon monoxide photoproduction from plant matter: J. Geophys. Res., 100, 11403-11413, 1995.

van der Werf, G. R., Randerson, J. T., Giglio, L., Collatz, G. J., Mu, M., Kasibhatla, P. S., Morton, D. C., DeFries, R. S., Jin, Y., and van Leeuwen, T. T.: Global fire emissions and the contribution of deforestation, savanna, forest, agricultural, and peat fires (19972009), Atmos. Chem. Phys., 10, 11707-11735, doi:10.5194/acp10-11707-2010, 2010.

Vasileva, A. V., Moiseenko, K. B., Mayer, J.-C., Jürgens, N., Panov, A., Heimann, M., and Andreae, M. O.: Assessment of the regional atmospheric impact of wildfire emissions based on $\mathrm{CO}$ observations at the ZOTTO tall tower station in Central Siberia, Geophys. Res. Lett., 116, D07301, doi:10.1029/2010JD014571, 2011. 
von Randow, C., Manzi, A. O., Kruijt, B., de Oliveira, P. J., Zanchi, F. B., Silva, R. L., Hodnett, M. G., Gash, J. H. C., Elbers, J. A., Waterloo, M. J., Cardoso, F. L., and Kabat, P.: Comparative measurements and seasonal variations in energy and carbon exchange over forest and pasture in South West Amazonia, Theor. Appl. Climatol., 78, 5-26, doi:10.1007/s00704-004-0041-z, 2004.

Ward, D. E., Setzer, A. W., Kaufman, Y. J., and Rasmussen, R. A.: Characteristics of smoke emissions from biomass fires of the Amazon region - BASE-A experiment, in: Global Biomass Burning: Atmospheric, Climatic, and Biospheric Implications, edited by: Levine, J. S., 394-402, MIT Press, Cambridge, MA, USA, 1991.

Ward, D. E., Susott, R. A., Kauffman, J. B., Babbitt, R. E., Cummings, D. L., Dias, B., Holben, B. N., Kaufman, Y. J., Rasmussen, R. A., and Setzer, A. W.: Smoke and fire characteristics for cerrado and deforestation burns in Brazil: BASE-B experiment, J. Geophys. Res., 97, 14601-14619, 1992.

Williams, J., Fischer, H., Hoor, P., Pöschl, U., Crutzen, P. J., Andreae, M. O., and Lelieveld, J.: Influence of the tropical rain forest on atmospheric $\mathrm{CO}$ and $\mathrm{CO}_{2}$ as measured by aircraft over Surinam, South America: Chemosphere - Global Change Science, 3, 157-170, 2001.

Wofsy, S. C., Harriss, R. C., and Kaplan, W. A.: Carbon dioxide in the atmosphere over the Amazon Basin, J. Geophys. Res., 93, 1377-1387, 1988.

Xueref, I., Gerbig, C., Fridlind, A., Lin, J. C., Wofsy, S. C., Daube, B. C., Ackerman, A. S., Smith, J. E., Sayres, D., Vellovic, J., Baumgardner, D. G., Wang, D., Weinstock, E., Andrews, A. E., Gottlieb, E. W., and Anderson, J. G.: Combining a receptor-oriented framework for tracer distributions with a cloudresolving model to study transport in deep convective clouds: Application to the NASA CRYSTAL-FACE campaign: Geophys. Res. Lett., 31, L14106, doi:10.1029/2004g1019811, 2004.
Yokelson, R. J., Christian, T. J., Karl, T. G., and Guenther, A.: The tropical forest and fire emissions experiment: laboratory fire measurements and synthesis of campaign data, Atmos. Chem. Phys., 8, 3509-3527, doi:10.5194/acp-8-3509-2008, 2008.

Yokelson, R. J., Crounse, J. D., DeCarlo, P. F., Karl, T., Urbanski, S., Atlas, E., Campos, T., Shinozuka, Y., Kapustin, V., Clarke, A. D., Weinheimer, A., Knapp, D. J., Montzka, D. D., Holloway, J., Weibring, P., Flocke, F., Zheng, W., Toohey, D., Wennberg, P. O., Wiedinmyer, C., Mauldin, L., Fried, A., Richter, D., Walega, J., Jimenez, J. L., Adachi, K., Buseck, P. R., Hall, S. R., and Shetter, R.: Emissions from biomass burning in the Yucatan, Atmos. Chem. Phys., 9, 5785-5812, doi:10.5194/acp-9-5785-2009, 2009.

Yurganov, L. N., McMillan, W. W., Dzhola, A. V., Grechko, E. I., Jones, N. B., and van der Werf, G. R.: Global AIRS and MOPITT CO measurements: Validation, comparison, and links to biomass burning variations and carbon cycle, J. Geophys. Res., 113, D09301, doi:10.1029/2007JD009229, 2008.

Yurganov, L., McMillan, W., Grechko, E., and Dzhola, A.: Analysis of global and regional $\mathrm{CO}$ burdens measured from space between 2000 and 2009 and validated by ground-based solar tracking spectrometers, Atmos. Chem. Phys., 10, 3479-3494, doi:10.5194/acp-10-3479-2010, 2010. 